San Jose State University

SJSU ScholarWorks

Master's Theses

Master's Theses and Graduate Research

Fall 2012

\title{
The Effects of Restored Aquatic Large Woody Debris Structures on Invertebrate Populations in the Napa River
}

Clayton Christopher Leal

San Jose State University

Follow this and additional works at: https://scholarworks.sjsu.edu/etd_theses

\section{Recommended Citation}

Leal, Clayton Christopher, "The Effects of Restored Aquatic Large Woody Debris Structures on Invertebrate Populations in the Napa River" (2012). Master's Theses. 4240.

DOI: https://doi.org/10.31979/etd.t2mq-zhm7

https://scholarworks.sjsu.edu/etd_theses/4240

This Thesis is brought to you for free and open access by the Master's Theses and Graduate Research at SJSU ScholarWorks. It has been accepted for inclusion in Master's Theses by an authorized administrator of SJSU ScholarWorks. For more information, please contact scholarworks@sjsu.edu. 
The Effects of Restored Aquatic LaRge Woody Debris STRUCTURES ON INVERTEBRATE POPULATIONS IN THE NAPA RIVER

\author{
A Thesis \\ Presented to \\ The Faculty of the Department of Environmental Studies \\ San José State University \\ In Partial Fulfillment \\ of the Requirements for the Degree \\ Master of Science
}

by

Clayton C. Leal

December 2012 
(c) 2012

Clayton C. Leal

ALL RIGHTS RESERVED 
The Designated Thesis Committee Approves the Thesis Titled The Effects of Restored Aquatic Large Woody Debris Structures on InVertebrate Populations in the Napa River by Clayton C. Leal APPROVED FOR THE DEPARTMENT OF ENVIRONMENTAL STUDIES SAN JOSÉ STATE UNIVERSITY

December 2012
Dr. Rachel O’Malley
Department of Environmental Studies
Dr. Will Russell
Department of Environmental Studies
Dr. Lynne Trulio
Department of Environmental Studies 


\section{ABSTRACT \\ The Effects of Restored Aquatic Large Woody Debris Structures on Invertebrate Populations in the Napa River}

by Clayton C. Leal

Agricultural encroachment and habitat destruction within the riparian zone of many California ecosystems have created a need for restoration of stream hydrology in order to enhance and support native flora and fauna. On the Napa River, adjacent vineyards have caused the channel to become deeply incised, so that the stream now lacks geomorphic variability and biodiversity. In order to restore channel complexity, large woody debris (LWD) structures were installed in the river in the summer of 2010. In this study I evaluated the effects of installing LWD structures within the Napa River on benthic invertebrates in the first year after installation. Six $150 \mathrm{~m}$ study sites were sampled monthly from June 2011 to September 2011 using the kick sampling method. Areas that received LWD treatment were compared to control sites of the same habitat type. Although in-stream invertebrate diversity and abundance varied with stream geomorphology along the length of the river, in no instance did invertebrate abundance increase in the first year after installation of large woody debris. In fact, in several months LWD structures were associated with lower invertebrate abundance and diversity as well as lower dissolved oxygen. Overall, added LWD did not function as planned at base flow during the first year after installation. 


\section{ACKNOWLEDGEMENTS}

First and foremost I would like to thank my family for their love and support through my entire academic career. My parents Doug and Lynn Leal, siblings Hattie and Tyson and my Grandma Dorothy always supported me and gave me the confidence and reassurance to follow my passion. Without all of them I would have never been able to succeed and become the person I am today.

I would also like to thank my research assistants Jeff Sinclair, Paul Nyhof, Pedro Hernandez, and Megan Gunvalson. They volunteered their time scrambling through the streambed, taking on the tedious task of sorting invertebrates. They were not only great assistants, but are also great friends. I would like to send a special thank you to Jeff Sinclair for not only volunteering for almost every sampling day, but always being available and willing to discuss ideas and provide insight throughout my entire project.

Dr. Rachel O'Malley not only served as my thesis chair, but as a mentor for my environmental career. She pushed me to excel and worked with me through all of the bumps along the way. Her guidance and direction proved to be invaluable. I would like to extend my gratitude to my committee members $\mathrm{Dr}$. William Russell and Dr. Lynne Trulio who provided support and guidance throughout my project.

Finally, I would like to thank Jeremy Sarrow of the Napa County Flood Control and Water Conservation District and Gretchen Hayes of Tessera 
Sciences for allowing me to work on this project and for providing access to my study site.

Financial Support from the San Jose State University College of Social Science Research Grant Foundation was greatly appreciated. 


\section{Table of Contents}

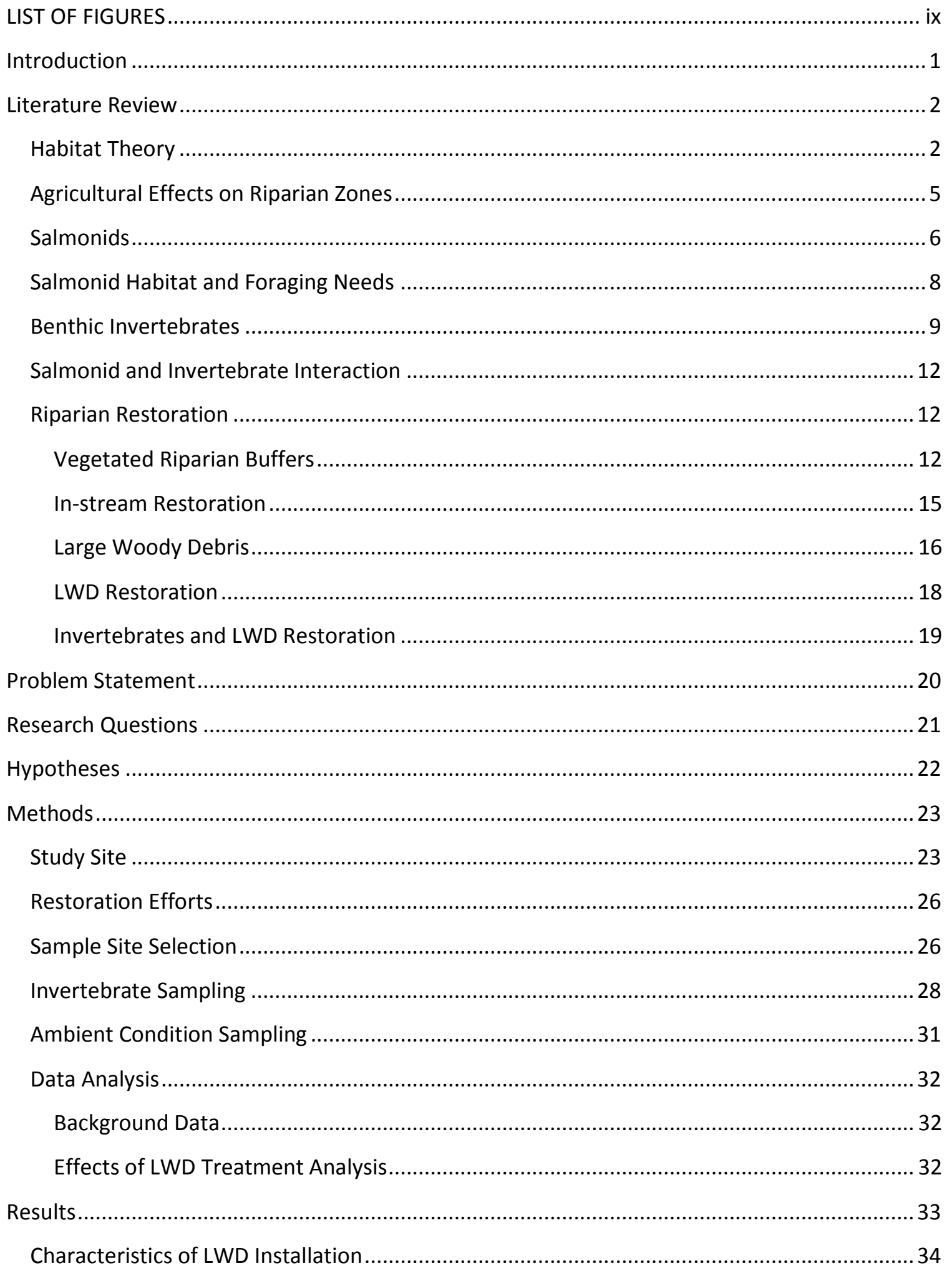




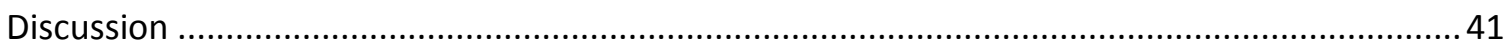

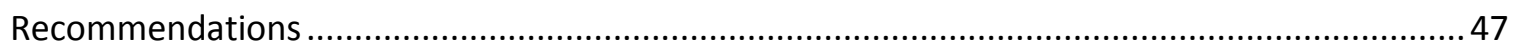

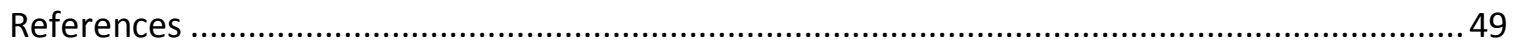




\section{LIST OF FIGURES}

Figure 1: Map of restoration site on the Napa River, Napa, CA....................... 25

Figure 2. Graphic interpretation of Control sampling points............................ 28

Figure 3. Graphic interpretation of $1.6 \mathrm{~km}$ study site................................... 28

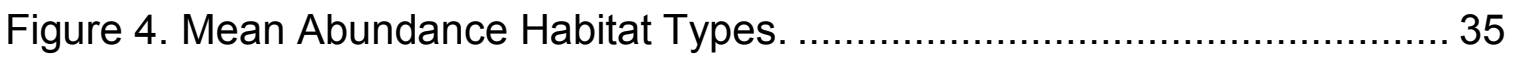

Figure 5. Substrate Size LWD Treatment vs Control ...................................... 36

Figure 6. Mean DO Levels Treatment vs Control ......................................... 37

Figure 7. August Invertebrate Abundance LWD Treatment vs Control ............... 38

Figure 8. August Species Richness LWD Treatment vs Control ...................... 38

Figure 9. August Medium size Class Abundance LWD Treatment vs Control.... 39

Figure 10. August Ephemeroptera Abundance LWD Treatment vs Control ....... 40

Figure 11. June Diptera Abundance LWD Treatment vs Control ....................... 40

Figure 12. August Diptera Abundance LWD Treatment vs Control ................... 41 


\section{Introduction}

Fertile lands associated with flood plains and river valleys have been the dominant landscape preferred by agriculturalists. Conventional agriculture in proximity to riparian habitats has caused environmental problems associated with water quality, water temperature, and habitat composition (Richards, Host, \& Aruther, 1993) that have reduced populations of anadromous fish and the invertebrates they feed on. To mitigate these problems riparian restoration projects are often implemented. In-stream habitat modification to enhance benthic invertebrate abundance can include installing large wood in the stream channel, channel diversions, and the creation of habitat such as pools and riffles.

In 2010, local and federal agencies commenced a restoration project on the main stem of the Napa River in California called the Rutherford Reach Restoration Project with the main goals of reducing erosion, sustaining biodiversity, and reducing agricultural impacts on the river system. In order to sustain biodiversity, the restoration project will seek to increase the habitat available to salmonids, including steelhead trout (Oncorhynchus, mykiss) and Chinook salmon (Oncorhynchus, tshawytscha). In portions of the restoration project, habitat features such as artificial riffles and log structures are being installed. In natural environments stream features such as riffles, runs, and pools are formed over time by the fluvial nature of the waterway, and woody debris is deposited naturally by overhanging canopy. In restoration projects, managers try to reinstate such stream features quickly, and sometimes in the absence of the 
ecological function that drives such features. Restorationists use information about the environment in a reference site or state as a model to create habitat they believe will enhance biotic suitability of the waterway being restored. When humans influence a river system, however, there is a chance it may not function in a natural way and may not provide habitat for all of the species found within the ecosystem.

\section{Literature Review}

\section{Habitat Theory}

A combination of human disturbance and habitat fragmentation has caused many riparian zones to lose their conjoined flowing nature and essentially become metaphorical islands of diversity, isolated by anthropogenic land alterations. These once diverse land areas now lack genetically diverse gene pools and diverse community composition (Holl \& Crone, 2004). When considering isolated habitats as islands, traditional island biogeography theory can be useful. Island biogeography theory predicts that immigration of new species increases and extinction rates decrease as a function of an isolated area's size. In small, fragmented islands, species richness reaches a point of equilibrium that is lower than the species diversity in areas that are larger and not isolated. Smaller and more isolated areas will have lower immigration rates and higher extinction rates, creating an area that is even less diverse (Macarthur \& Wilson, 1967; Anderson \& Waits, 2001). 
The idea of island biogeography as it relates to fragmented riparian habitats was tested by Harding, Claassens, and Evers (2001) in a study looking at fragmented forested riparian ecosystems and the effects of benthic invertebrates. These authors determined that the taxonomic richness was highest in continuously forested sites that lacked anthropogenic fragmentation. In the case of this study, many of the endemic species are now isolated in the remaining naturally intact forests, and these sensitive species have not been able to establish in the fragmented areas (Harding, Claassens, \& Evers, 2001).

The effects of the isolated island habitats can be minimized through the use of corridors. In fragmented landscapes corridors are essential for conservation of species, and linear habitat retention is essential to maintain diversity (Simberlof, Far, Cox, \& Mehlman, 1992; Spackman \& Hughes, 1994). With an increase in habitat destruction, species lose available habitat and experience genetic isolation. Corridors encourage movement of individuals via links among habitat patches and facilitate movement through unsuitable habitats. In the presence of a corridor, the risk of extinction and inbreeding are reduced (Berggren, Birath, \& Kindva, 2002). The theory based on corridors uses both island biogeography and population biology. Corridor design reduces the isolated nature of individual habitats and considers how species demography will be affected by the corridors being established. The presence of corridors increases the immigration rate between isolated areas, which mitigates effects of 
small population size and promotes re-colonization after extinctions (Kupfer, 1995).

These theories are most often applied to terrestrial environments, but they can be applied to benthic communities as well. Stream features and zones can become isolated by areas that do not facilitate the basic needs of the species. If poor habitats can be restored, habitat linkage can be obtained and the effects of fragmentation can be mitigated. Riparian species need the ability to successfully travel through the stream system to ensure all needs will be met. Without the linkage of stream habitat types, structure and local assemblages can be altered (Taylor, Melvin \& Warren, 2001).

Streams as corridors are not only looked upon as the linear wetted portion of the stream, but also as interconnected biosphere of land and water. Based upon literature of the 1970s and 1980s the stream corridor is described by the linkage of stream channel, riparian zones, and hyporgeic zones as well as the broad reaching stream basin including the flood plain an catchment hydrology (Poole, 2010).

The stream corridor is commonly referred to as a linear transect along the stream channel with radial hydrologic linkages stretching into the surrounding catchment, floodplain, riparian zone, and alluvial aquifer (Poole, 2010). The stream corridor can also be defined as a river mosaic. This concept depicts the river continuum as the entire river system including the water, organic matter, fish, invertebrates, and many other stream features as they change along the 
course of the river course. The mosaic of variation is connected by corridors that allow the diversity within the patches to survive (Forman, 1995). Since the resources within a fluvial system tend to vary at any given time, organisms move to fulfill their basic needs.

\section{Agricultural Effects on Riparian Zones}

The link between agriculture and riparian habitat destruction has been recorded in many studies (Duehr, Siepker, Pierce, \& Isenhart, 2008; Richards, Host, \& Aruther, 1993). When considering impacts on riparian zones, disturbances can be broken into two different types, press and pulse. Press and pulse disturbances are based on the duration of time their effects are felt on the system. Press disturbance is a long-term effect, which includes land alteration and habitat destruction. Pulse is a short-term yet high impact disturbance such as a chemical spill (Stone \& Wallace, 1998). Agricultural practices within the riparian zone cause both pulse and press disturbances. Encroachment on streams and severe land clearing fall under the category of press disturbance, while pesticide and fertilizer runoff, are pulse disturbances.

Agricultural practices are a main source of non-point pollutants entering river systems (Wauchope, 1978). Streams adjacent to agricultural lands receive inputs of pesticides and fertilizers via soil particles during runoff events (Jergentz, Mungi, Benetto, \& Schulz, 2005). In addition to the direct physical inputs of agricultural chemicals, agricultural practices lead to a decrease in biological diversity (Nicholls, Parrella, \& Altieri, 2001). The natural areas surrounding 
agricultural lands are simplified by expanding agricultural activities, including vegetation clearing, and land grading. Most salmonids that live in the streams and rivers surrounding the agricultural areas are threatened by all these farming practices. Viers (2008) assessed management practices for anadromous fish and determined that freshwater habitat used for spawning and young development plays the most crucial role in the survival of the anadromous species, so more attention should be paid to these habitats.

\section{Salmonids}

Salmonids, comprising Oncorhynchus, Salmo, and Salvelinus species, are found throughout the world in cool streams and lakes. In addition to intrinsic ecological value, salmonids have also provided valuable resources for human existence for thousands of years (Netboy, 1958). In North America, salmonids have supported human culture, survival, and economic success (McEvoy, 1986). With the shift from the subsistence fishing of the Native cultures to the profitdriven fishing industry of the 1800's, as well as severe habitat destruction through dams and diversions, salmonids have declined, and in some instances failed to return to their historic drainages. With this decline, a flood of conservation efforts, research, and restoration efforts have been established in attempt to protect these resources. Many factors contribute to the success and failure of the species as well as the efforts involved in restoration. Though common needs are present, different genera and ecotypes of salmonids have 
varying biological needs that must also be taken into consideration (Kondolf, 2000).

Salmonids fall into two categories in reference to their migratory habits. Anadromous salmonids hatch in freshwater rivers and travel to the ocean to spend their adult lives, then return to spawn in fresh water. Potamodromous species reproduce and spawn in the freshwater rivers and spend their adult lives migrating within that river system. Since restoring habitat in the open ocean phase of the anadromus salmonids' lifecycle is very difficult, most efforts take place in their natal streams, where the majority of the damage has been done. These in-stream efforts also enhance habitat for potamodromous salmonids, which are able to benefit year-round (Kondolf, 2000).

Changing stream morphology to enhance habitat for salmonid populations has proven successful in increasing population dynamics, abundance, and reproductive success in a wide range of studies (e.g: Gowan \& Faush, 1996; Johnson, Breneman, \& Richards, 2002; Johnson et al., 2005; Veirs, 2008). Gowan and Faush (1996) concluded that in order for changes in morphology to be beneficial to salmonids, habitat requirements of the fish need to be assessed and morphological changes need to occur to provide what is lacking in the habitat. This requires studies of pre-habitat manipulation to be carried out, to determine what the population of salmonids is lacking. Gowan and Faush (1996) believe it is impossible to create generic criteria for morphology manipulation, and that variables associated with individual drainages must be considered. 


\section{Salmonid Habitat and Foraging Needs}

Habitat type affects the ability of salmonids to forage for food. Habitat structure influences food availability within an ecosystem and regulates fish ability to encounter and capture food (Rosenfeld \& Taylor, 2009). Salmonids are size-selective predators, and they often show a strong preference for the largest naturally-occurring prey available. Salmonids are drift-feeding, sit and wait predators, which wait for food sources to come to them (Meissner \& Muotka, 2006). Rosenfeld and Taylor (2009) researched the effects of habitat manipulation on the ability of cutthroat trout (Oncorhynchus clarki) to forage for food. Altering the proportions of pool and riffle habitat within the stream affected the volume of invertebrates to drift, which is necessary to present the invertebrates as a food source for salmonids. If changes in habitat create areas of reduced or increased flow rates, the ability and energy expenditure of salmonids to feed changes, which can affect salmonid growth and survival rates (Rosenfeld \& Taylor, 2009).

Substrate size and gravel embeddedness can also impact salmonid growth and survival rate. Not only do adult fish need gravel of adequate size and permeability, but young fish health can also be directly impacted. Suttle, Power, Levine, and McNeely (2004) determined that small substrate and increase embeddedness reduces growth rates, increases required energy expenditure, and reduces food availability to young salmonids. 


\section{Benthic Invertebrates}

Biomass of salmonids is directly related to the availability and densities of aquatic invertebrates (Romaniszyn, Hutchens, \& Wallace, 2007). Invertebrate structure is affected by the presence of riparian vegetation. In zones with increased canopy cover and less agricultural land cover macroinvertebrate community increases (Rois \& Bailey, 2006). The removal or reduction of riparian vegetation can alter the food web in a stream. Not only does it have an effect on benthic invertebrates but can alter the terrestrial invertebrate availability to fish and other species (England \& Rosemond, 2004). Riparian vegetation provides much of the food base that supports the aquatic ecosystem. Vegetation on the stream bank supports organic material inputs such as leaf litter and dissolved nutrients which sustain invertebrate populations. Dissolved nutrients are carried into the stream by groundwater passing through the root system. Vegetation can regulate the flow of these nutrients and control dispersal into the system. In

diverse riparian buffers, seasonal variability of inputs from senescing leaves provides leachates of different chemical contents which provide nutrients for a broad assemblage of invertebrates (Gregory et al., 1991).

The feeding guilds of benthic invertebrates can be broken into categories of organisms that feed essentially on detritus or the bacteria in the benthic layer, filter feeders that retain plankton and small pieces of suspended detritus, herbaceous grazers, or carnivores that feed on living organisms (Gamito \& Furtado, 2009). These categories can then be separated into what are known as 
functional groups. Those that are feeding in the benthic layer on detritus and graze on algae and epiphytes are known as shredders; suggesting their ability to break down larger particles into manageable forage (Richards et al., 1997; Duehr et al., 2008). Those that feed on smaller particles suspended in the water column are collectors, and have adapted to retain food as it flows through the system. The carnivorous benthic invertebrates fall into the functional group of predators (Duehr et al., 2008).

Rios and Bailey (2006) conducted research on the direct relationship of benthic invertebrates to riparian vegetation. Vegetation types were classified in buffers, different stream reaches, and different basins by comparing vegetation types to the benthic macroinvertebrates assemblage within the stream. Rios and Bailey (2006) did not consider basin land use characteristics and solely focused on vegetation features such as tree, shrubs, and herbaceous cover. Using stream basin as a spatial scale provided little valuable information and it was determined that local factors contribute more to invertebrate assemblage. The researchers were able to draw correlation between canopy cover and invertebrate assemblage, but stated that future analysis on land characteristics would provide beneficial insight to the connection between riparian vegetation and benthic macroinvertebrates (Rios \& Bailey, 2006).

Since invertebrates are ectothermic, stream temperature directly affects their metabolic processes and their abundance and distribution in the stream. Geomorphic variation in the streams as well as the presence of shading 
vegetation regulates temperature in a stream. In a study by Hawkins, Hogue, Decker, and Feminella (1997) on California montane streams it was determined that channel morphology and hydrology were the major contributor to regulating water temperature. In California summers when air temperatures increase and stream flow decreases, water temperature can alter the abundance and distribution of invertebrates. In a stream with a diverse morphology (riffles, pools, and glides) the adverse effects of temperature can be mitigated (Hawkins et al., 1997).

The use of heavy machinery to restore riparian systems can have a negative effect on the habitat, even after the work is completed. During the restoration, properties associated with stream characteristics essential to habitat for benthic invertebrates can be lost. For example, when stream channels are altered and new morphological structures are added, a decline in benthic mosses results (Matouka \& Laasosen 2002; Matouka, Paavola, Haapala, Novikmec, \& Laasosen, 2002). Moss along the streambed creates essential habitat and a food source for some benthic invertebrates. When moss is lost, the assemblage and structure of the invertebrate communities decrease. Matouka et al. (2002) therefore suggest that during the restoration process, patches of undisturbed stream should be left to serve as a source of re-colonization for the entire streambed. 


\section{Salmonid and Invertebrate Interaction}

Both potanadromous and anadromous salmonids feed on drifting benthic and terrestrial invertebrates. Though some populations feed on a combination benthic and terrestrial diet, others will depend mainly on benthic invertebrates, depending on habitat types (Tippets \& Moyle, 1978).

Salmonids are limited by the availability of benthic invertebrates. Larger predatory invertebrates like some stoneflies (Plecoptera, spp.) species provide a valuable food source for salmonids. Predatory invertebrates actively hunt and pursue prey, which in some cases can make them more vulnerable to becoming forage for trout (Soluk \& Richardsons, 1997; Tippet \& Moyle, 1978). Soluk and Richardson (1997) determined that an increase of stonefly availability to salmonids provided short-term gains in the fish's ability to forage and stimulate growth of the individuals. In a study of stomach content of rainbow trout (Oncorhynchus mykiss) it was found that active large benthic invertebrates including stoneflies, mayflies (ephemeroptera, spp.), and caddis flies (Trichoptera, spp.) made up the majority of the fishes' diet, thus outlining the importance to the survival of the species (Tippet \& Moyle, 1978).

\section{Riparian Restoration}

\section{Vegetated Riparian Buffers}

To mitigate effects of habitat destruction and to maintain water quality, vegetated riparian buffers (VRB) are sometimes restored (Duehr et al., 2008). 
VRBs are vegetated lands between stream channels and the agricultural fields that act as a vegetated filter zone (Borin, Passoni, Thiene \& Tempesta, 2010). According to Luke, Luckai, Burke, and Prepas (2007), riparian buffers act as a transition zone from terrestrial to aquatic ecosystems, which is essential for controlling the flow of energy and nutrients as well as the biotic interchange. VRBs are necessary to regulate the microclimate features within the freshwater habitats, which include light, temperature, and humidity (Gregory, Swanson, Mckee, \& Cummins, 1991; Naimen, Decamps, \& Pollock, 1993; Rios \& Bailey, 2006). Riparian buffers create corridors along the stream channel that support an abundance of flora and fauna (Ma, Tarmi, \& Helenius, 2002). According to Naimen, Decamps, and Pollock (1993) natural riparian corridors are the most diverse and dynamic biophysical areas on the terrestrial portion of the earth.

Riparian vegetation surrounding the stream bank works to regulate the amount of solar radiation available to the aquatic system and determines how heat will be exchanged and distributed through the aquatic area (Osborne \& Kovacic, 1993; Poole \& Berman, 2001). VRB zones provide thermal protection needed to regulate temperature and provide for adequate levels of dissolved oxygen (DO) (Luke et al., 2007). If vegetation is removed or altered, the change in microclimate can render the habitat unsuitable for native species and alter the assemblage of species (Poole \& Berman, 2001). Though other factors such as geography and groundwater inflow have an effect on stream water temperature, the composition and density of the vegetation plays an important role (Osborne \& 
Kovacic, 1993). Regulation of temperature is essential to a stream's ability to support aquatic species. The temperature of streams influences metabolic rates, physiology, and life cycles of aquatic species and can regulate nutrient cycling (Poole \& Berman, 2001). A temperature differential of just $\sim 2.0^{\circ} \mathrm{C}$ separates streams that can possibly support young salmonids and streams that will not support them during their vulnerable life stage (Jones, Poole, Meyer, Bumback, \& Kramer, 2006).

Ma et al. (2002) determined that the richness of plant species along a buffered stream could be increased by widening the buffer strip instead of lengthening it. The width of a buffer not only increases its function, but increases the biodiversity of the landscape. In a comparison of buffer width versus length increase, buffer width contributed more to an increase of plant species richness (Ma et al., 2002). Duehr et al. (2008) took a different approach to monitoring the effect of VRB. No emphasis was put on the width of the VRB or what specific vegetation was established. The researchers instead assessed the length of time the buffer had been in place compared to unbuffered areas. Vegetation was not classified or described in the article, rather success was measured based on velocity of stream flow, substrate, water depth, and assemblage of invertebrates and fish within the established zones. This study determined that the site that had been buffered the longest (11 years) had a higher species assemblage than both the unbuffered sites and the site that had been buffered for 3 years, even 
though the researchers found no significant differences in stream flow, substrate, or water depth (Duehr et al., 2008).

Lorion and Kennedy (2009) employed a combined vegetation classification and buffer width approach. This study looked at buffered streams adjacent to pasture land with a width that averaged a minimum of $15 \mathrm{~m}$, which was forested, compared to non-buffered areas adjacent to pasture land. Lorion and Kennedy also used a naturally forested stream as a form of control to draw conclusions not only on buffered versus non-buffered, but to see how buffered streams compare to their natural counterparts. Fish assemblage was used as a proxy to determine quality of the habitat. The research determined that naturally forested streams were similar in assemblage of fish species to VRB with an average width of $15 \mathrm{~m}$. Non-buffered areas assemblages were very distinct and not normally found in streams of the same size and geographical location. This project only looked at forested buffers, since it was within an area with logging activities. A separate study conducted by Kreutzweiser, Capell, and Holmes (2009) looked into logging thinning regimes within riparian buffers. They also used a natural unaltered forested stream as a form of control and determined that partial harvest of trees to $50 \%$ of total cover created an environment much the same as the natural stream in terms of water temperature.

\section{In-stream Restoration}

The success of a restored ecosystem is often measured by the diversity of the species and the recovery of biotic features, but often fails to measure 
success of ecosystem processes. Flora and fauna within an ecosystem usually follow a cyclic pattern. If researchers conduct post-restoration monitoring during a peak or lull in the cycle, misleading results can be obtained. Comparing and evaluating the functionality of the restored habitat can determine whether the system can sustain natural levels of biodiversity (Palmer, Ambrose, \& Poff, 1997). According to Cummins, Wilzbach, Gates, Perry, and Taliaferro (1989) (as cited by Matouka \& Laasosen, 2002) biotic communities are heavily dependent on detritus that enters the stream during the autumn senescence. The authors suggest that the amount of leaf litter that enters the stream is not as important as the stream's ability to retain the leaf litter within the fluvial system. Matouka and Laasosen (2002) evaluated restored habitat's ability to retain leaf litter and compared benthic diversity pre-and post-restoration with that of a naturally occurring stream. Restored systems had the ability to retain litter at an increased capacity to pre-restoration, but lacked the efficiency of a natural system. The benthic invertebrate diversity was also higher post-restoration, but did not compare to the natural stream. This study suggests that restoration can provide an increase in diversity and create a habitat that is more suitable than the degraded area, but preservation of intact habitat is still the best practice.

\section{Large Woody Debris}

Large woody debris (LWD) works to shape the stream morphology, retains sediment, and creates in-stream habitat (Gregory et al., 1991; Ma et al., 2002). The recruitment of LWD into a river system is a function of buffer width and stand 
density. Research conducted in Southeast Alaska on buffer strip size and its input of LWD concluded that a buffer width of $20 \mathrm{~m}$ provided sufficient recruitment. At the study site $96 \%$ of LWD recruited into the stream came from less than $20 \mathrm{~m}$, and the researchers believe the $4 \%$ loss would not significantly alter the make-up of the stream (Martin \& Grotefendt, 2007). In areas of degraded habitat natural recruitment of LWD does not occur. The installation of LWD into the stream channel is a common practice during riparian restoration. LWD creates habitat used by the fish in both low-water summer flows and high winter flows. In the summer, pools and backwaters are created by LWD, which allows for water to remain deep and cool enough for the fish to survive. Areas below created pools are formed into what are known as plunge pools. The water flowing over or under the LWD becomes oxygenated due to mechanical mixing, which is beneficial during times of reduced flows (Mossop \& Bradford, 2004). In the winter, when flood conditions arise, the LWD creates an area of reduced flows and eddies to keep the fish from being washed down-river. Yearround, the presence of LWD creates habitat that allows for fish to hide from predators as well as an area to perform as predators (Wing \& Skaugset, 2002). Johnson et al. (2005) confirm that LWD creates essential habitat for salmonids during winter floods and summer low flows. Their research determined that salmonid survival increased when LWD was present in the system. LWD provides habitat and a food source for invertebrates. Invertebrate richness is well established to increase in the presence of LWD (Johnson, 
Brenemen, \& Richards, 2003; Hrodey, Kalab, \& Sutton, 2008). Hrodey, Kalab, and Sutton (2008) for example, took pre-and post-treatment samples of benthic invertebrates in a stream restored with LWD. Surveys conducted after LWD was installed showed significant increases in relative abundance and taxon richness of macroinvertebrates.

LWD is installed into the stream using different methods and positioned to achieve different results. When artificially establishing LWD into a system, considerations must be made in order to allow for the productivity of the wood to be seen. The presence of LWD is a natural occurrence in streams and rivers, and when it is being restored this factor must be considered. LWD is not beneficial if it is placed haphazardly in the stream channel. The location of the LWD should depend on the goal of the establishment of the wood. Locations will vary if LWD is established for roughness to slow flows, to create scour pools, or for regulating sediment loss (Kondolf, 2000). The size of trees used as LWD also plays a role in creating habitat. Small trees both in diameter and length will form different habitat and retain sediment in a different fashion than larger trees. The presence of root wads, branches, and even leaves alter flows and are variables that should be evaluated when starting an LWD restoration (Magilligan et al., 2008).

\section{LWD Restoration}

LWD can be installed using two different approaches. The most common approach is anchoring the logs in the stream bed by burying, anchor, and cabling 
(Shields, knight, Morin, \& Blank 2003; Hrodey, Kalab, \& Sutton, 2008). This method allows the restoration team to have more control and to engineer the structures to produce a desired outcome. The other method involves putting the wood into a stream unanchored. This allows for natural deposition and habitat creations (Brooks, Gehrke, Jansen, \& Abbe, 2004; Johnson et al., 2005). Though trees are not anchored using anthropogenic attributes often times they will be wedged or placed so that they remain stationary (Johnson et al., 2005).

Sweka and Hartman (2006) took unanchored LWD implementation to the next level. They only used trees already established on the stream bank, which were felled into the streambed at the same angle they would naturally have fallen. Once trees were cut, they were only touched if they were not in contact with the water. This method is only practical in streams with remaining riparian buffers and when LWD structures purpose does not need to be defined. This method must also consider other potential impacts associated with the use of established trees.

\section{Invertebrates and LWD Restoration}

LWD in streams creates conditions that positively affect invertebrate communities. LWD creates a heterogeneous habitat features that allow for a wide range of niches to be available (Schneider \& Winemiller, 2008). Johnson, Brenemen, and Richards (2003), and Hrodey, Kalab, and Suttons (2008) determined that the presence of restored LWD increased abundance and diversity of macroinvertebrates, yet both found that other habitat features 
contributed to the increase. The theory that installed LWD increases invertebrate abundance is an area of controversy. The studies mentioned above have experienced positive results, but others have experience little to no change. Lepori, Palm, Brannas, and Malmqvist (2005) experience results that diversity did not change after LWD installation. In a review article that performed a metadata analysis on twenty-four different studies on the installation of LWD they found inconclusive results in relation to LWD increasing invertebrate abundance. They were confident enough to say that the installation of LWD could potentially increase diversity, but no statement could be made on the effects on abundance (Miller, Budy, \& Schmidt, 2010).

By considering previous research conducted, and using methods and theories that have been applied to other restoration projects I have formulated a study plan based on their success and failures. By reviewing previous research and adapting my study to include successful attributes, it has the opportunity to be a valuable resource within the field of restoration. Since benthic invertebrates are essential to the food chain, their success can be directly related to the success of other species within the system.

\section{Problem Statement}

With increasing riparian encroachment and streambed alterations, accompanied with the loss of biodiversity, the need for riparian restoration is growing. Funding and support for these restoration projects often comes in association with the presence of listed and rare species. Since the support is 
focused on listed steelhead/rainbow trout and Chinook salmon, monitoring is focused to show their success. Emphasis is placed upon presence or absence of the species, increase in population, and creation of available beneficial habitat. This type of species-centric monitoring can fail to determine the overall success of the project. Without considering all facets of a functionally restored ecosystem, key features can be missed and project failures can go unrecognized.

In the Rutherford Reach Restoration Project, limited habitat for endangered salmonids is a concern. Benthic invertebrates are the main food supply for salmonids and are essential for salmonid survival during certain life stages. Like most restoration projects, no consideration was given to the need for monitoring of lower trophic level species. Consideration is given to the presence and absence of salmonids and monitoring is being performed on available habitat. The basic need of food is an area that is overlooked. The objective of this study was to evaluate whether artificially created large woody debris structures indeed enhance in-stream invertebrate diversity and abundance in the first year after installation, or whether their effects can be uncertain or even initially counterproductive.

\section{Research Questions}

In order to determine the impact of the installation of artificial LWD structures on benthic macroinvertebrates and their habitat, the following questions were addressed. 
1. How did different reaches across the study site vary in terms of the following habitat characteristics:
a. canopy cover?
b. submerged tree roots?
c. undercut banks?
d. emergent vegetation?
e. algal cover?
f. barren ground?

2. How did the installation of artificial LWD structures in a low gradient California stream affect:
a. benthic macroinvertebrate diversity?
b. total benthic macroinvertebrate abundance?
c. DO levels?
d. substrate size?
e. water temperature?

\section{Hypotheses}

Based on previous literature, artificial LWD structures installed as part of this restoration were expected to have the following effects on and ambient conditions on physical and biological parameters.

H1: Sampling reaches will not differ in:

a. canopy cover, 

b. submerged tree roots,
c. undercut banks,
d. emergent vegetation,
e. algal cover, or
f. barren ground.

H2: Compared to unrestored control sites, artificial LWD structures will result in:

a. a higher diversity benthic macroinvertebrate compared to un-restored control sites.

b. a higher abundance of benthic macroinvertebrate compared to the un-restored control sites.

c. a higher DO level compared to un-restored control sites.

d. a larger average substrate size compared to un-restored control sites.

e. cooler water temperatures compared to the un-restored control sites.

\section{Methods}

\section{Study Site}

This study was conducted on the main-stem of Napa River in Napa County, California. The Napa River is the third largest tributary of San Francisco Bay at approximately $80 \mathrm{~km}$ long. The river stretches from headwaters on Mount St. Helena and ends in San Pablo Bay at the Carquinez Straits. The lower 
watershed is tidally influenced and is brackish for approximately $34 \mathrm{~km}$. The upper portion of the watershed is situated within the Napa Valley between the Vaca and Mayacamas mountain ranges. The watershed within the Napa River system drains $644 \mathrm{~km}^{2}$ of land through its 53 tributaries. Currently, the Napa River is listed as impaired and is regulated by the Clean Water Act Total Maximum Daily Load (TMDL) action because of the excessive amounts of sediment that enter the system (Hayes, Michelli, \& Mackay, 2010).

The study site was north of the City of Napa, between the small towns of Yountville and Saint Helena (Figure 1), within, the Rutherford Reach Napa River Restoration Project. This project included $7.2 \mathrm{~km}$ of riparian habitat which is not tidally influenced. The elevation ranges from $58 \mathrm{~m}$ on the upstream portion to 40 $\mathrm{m}$ at the downstream reach. This reach of the river is comprised of forty individual parcels owned by 29 private entities. Land use practices and riparian encroachment has forced this portion of the river to run in a confined channel, which has caused increased bank erosion, increased invasive plants, and an overall loss in riparian and wetland habitats. The restoration project was broken into nine different reaches, but sampling for this study occurred only in reach 1 through 5 (Hayes et al., 2010). 


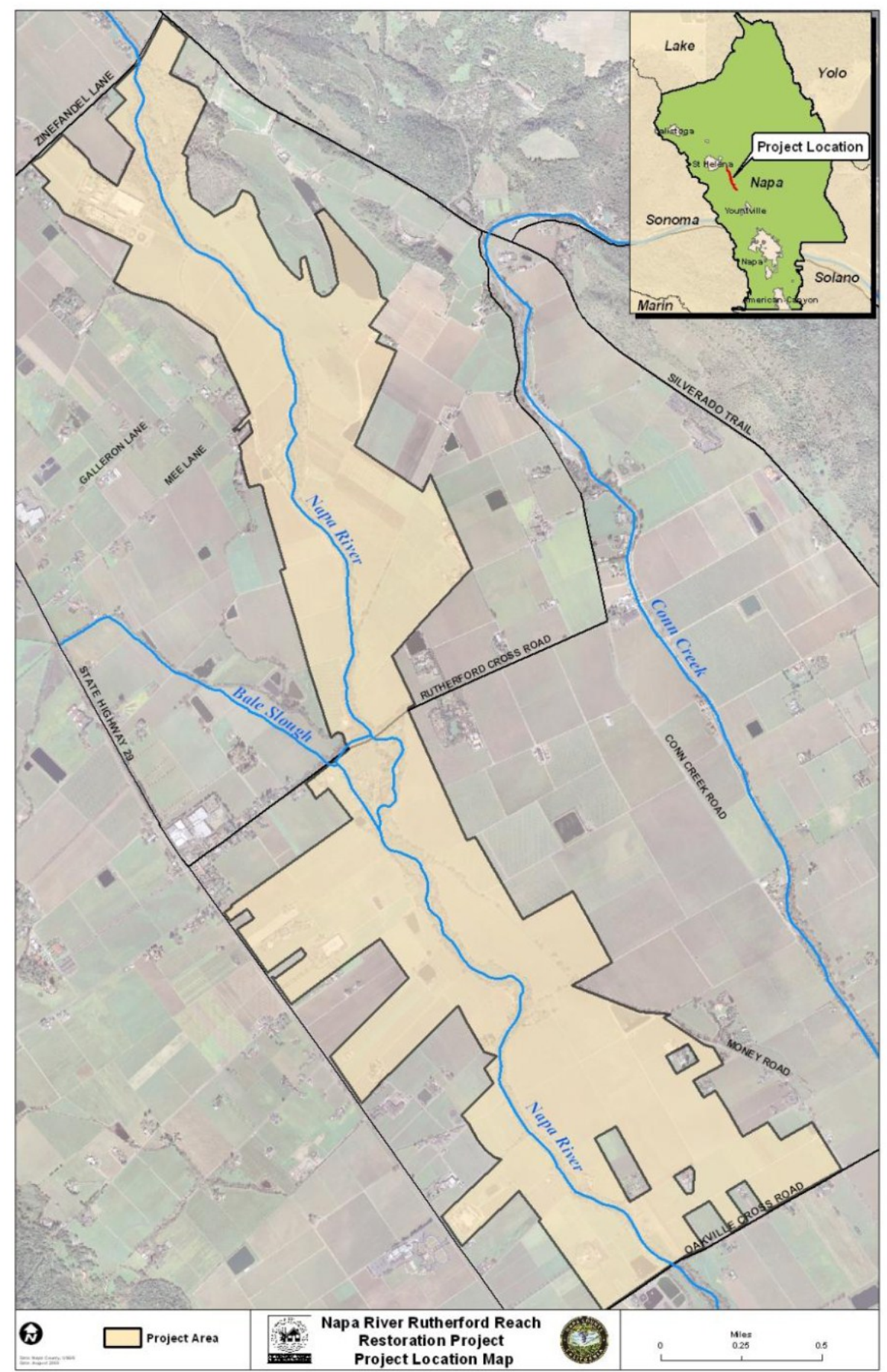

Figure 1: Rutherford Reach Restoration Project site on the Napa River. Image courtesy of Jeremy Sarrow Napa County Flood Control District (Sarrow, 2011). 


\section{Restoration Efforts}

In the summer of 2010, Jones and Stokes Consulting, Teressa Consulting, and the Napa Flood Control and Water Conservation District installed five LWD structures. The overarching goal was to create habitat to benefit salmonids. These structures were designed to act as naturally occurring log jams. Referred to as spider logs and bench logs, the structures consist of large pieces of wood (20 cm DBH minimum, greater than $2 \mathrm{~m}$ in length) placed in an "interlocking framework" (Hayes, Sarrow, \& Sharp, 2011). They were installed on a boulder footing and held in place by cabling to logs anchored into the stream bank, and to boulder anchors. All boulders, including the footing, were sized to prevent downstream transport. They were installed in the wetted portion of the channel at base flow, and were designed to constrict the channel, and to increase flow velocity. Conceptually, the structures would create more turbulent conditions, complex flow pattern, scour and deposition, bed material sorting, diversity in the

channel, and winter refugia for salmonids. Installation occurred in on-channel pools with very little habitat diversity (Hayes, Sarrow, \& Sharp, 2011).

\section{Sample Site Selection}

On August 11, 2010, I established six sampling reaches. Each sampling reach was $150 \mathrm{~m}$ in length and was selected using the engineer-station system (measurements in feet, starting at the confluence moving upstream) established by the Rutherford Reach Restoration Project. Each 150 m reach was broken into 
five equally spaced transects (Figure 2). Reaches were selected to include proposed LWD structures as well as control areas with no treatment. The sampling reaches were selected prior to installation of the wood structures. An area, $30 \mathrm{~m}$ upstream of proposed structures, was selected as a start point and four other transects were established at $30 \mathrm{~m}$ increments downstream. Reaches not containing artificial structures were established between treatment reaches as a control. Start points were randomly selected on a map, and then transects were designated downstream at $30 \mathrm{~m}$ increments. These reaches and transects were used to collect background information on the system, and allow for any upstream and downstream effects to be observed.

Six paired LWD treatment and control transects were established for the treatment versus control analysis. Once the wood structures were installed, an unaltered sampling point of the same habitat type was selected within the $150 \mathrm{~m}$ of the structure (Lepori et al., 2005) (Figure 3). No pairing occurred outside of the $150 \mathrm{~m}$ reach that was established for the background analysis. Since one of the log structures spanned $28 \mathrm{~m}$, it was sampled in two locations: one at the upstream extent and one downstream at the very end of the structure. Since no treatments were installed in riffle habitats, this habitat type was not compared to any of the treatments. The riffle habitats were, however, used in an initial analysis to evaluate background abundance and diversity in naturally occurring geomorphological features. 


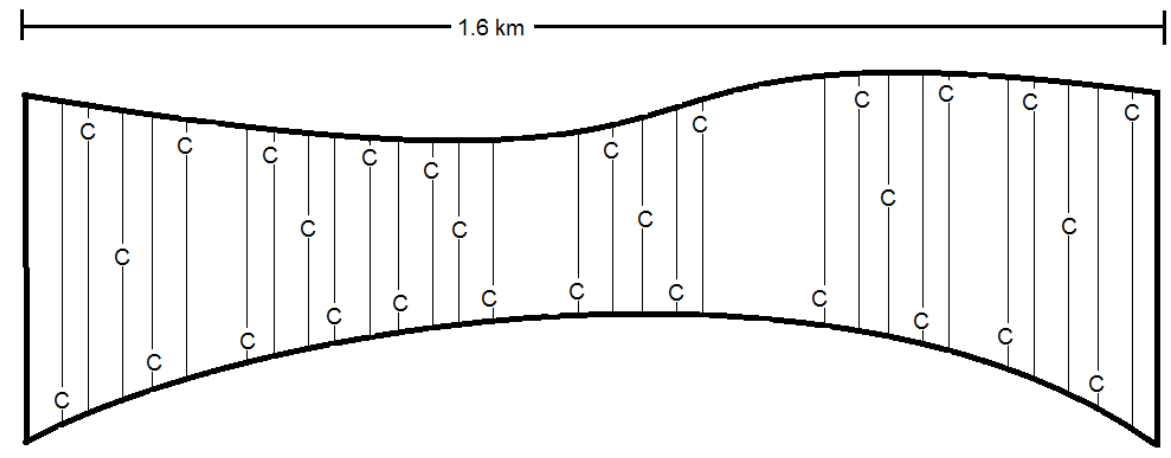

C-Control Sampling Points

Figure 2. Graphic interpretation of randomly selected Control sampling points. Sampling sites along the transect alternate between right bank, left bank, and thalweg.

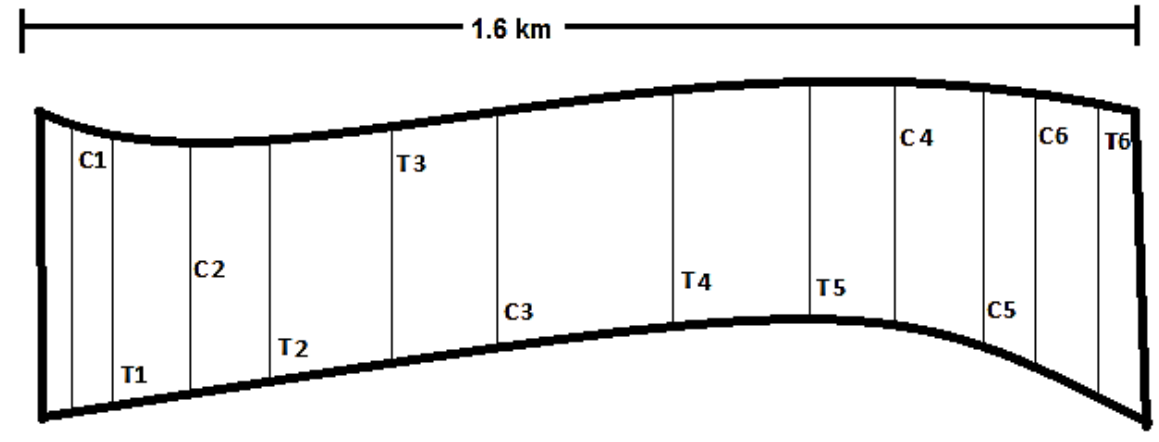

T- LWD Treatment Site

C-Unaltered Control Site

Figure 3. Graphic interpretation of $1.6 \mathrm{~km}$ study site. Control site indicated with "C" and LWD treatments with a "T". Numbers indicate treatment and control pairing of nearest habitat types.

\section{Invertebrate Sampling}

Invertebrate sampling starting dates in 2011 were: June 26 , July 27 ,

August 25, and September 25. Sampling periods were two consecutive days 
and started at the downstream end of the sample area. A D-frame kick net with mesh size of $500 \mu \mathrm{m}$ was used to collect all invertebrates (Gortz, 1998; Johnson, Breneman, \& Richards, 2003; Heino et al., 2005; Ode, 2007). I collected samples using methods adopted from the SWAMP protocol under the Reachwide Benthos (multihabitat) Procedure. Sampling points at each transect alternated between right bank, left bank, and thalweg, through the reach (Ode, 2007). All LWD treatment sampling points were taken within $0.10 \mathrm{~m}$ of the base of the structure on the downstream side. A $0.09 \mathrm{~m}^{2}$ quadrant of streambed was disturbed with the D-frame net held downstream of the quadrant. The upper layer of substrate was disturbed, exposing the underlying bed, and dislodging invertebrates (Ode, 2007; Blocksom, Autrey, Passmore, \& Reynolds, 2008). I thoroughly cleaned and inspected nets between sampling events to make sure no invertebrates were retained in the mesh (Growns, Schiller, O'Connor, Cameron, \& Gray, 2006).

With the aid of research assistants large debris such as rocks and pebbles were removed from the net after each sample, making sure no invertebrates were clinging to the materials. Invertebrates were then separated from the remaining substrate using tweezers and bodkins and placed into storage containers containing $95 \%$ ethanol. All glass storage containers were labeled with the date, sample site, and transect number, on both inside an exterior of the jar. 
Samples were taken back to the lab where I sorted invertebrates into morphospecies and identified them to order and family using Fredricks Stehrs, Immature Insects. If I was unable to identify to family, invertebrates were categorized by order and morphospecies (Growns et al., 2006). Taxonomic groups were recorded on a data sheet along with sample site information including date sampled, transect, and number of individuals. After sorting, all invertebrates were placed in containers by morphospecies and kept for future analysis.

After all sampling and sorting was complete, length and width of ten individuals of each morphospecies was measured. Similar to Tippet and Moyle (1978), who used volume as an index of abundance, I used a body mass surface area calculation for relative invertebrate abundance. For each morphospecies, the number per site was muliplied by the appropriate index and summed to assess invertebrate abundance for each sampling site.

A Simpson's diversity index was calculated for each sample, to describe the variation in invertebrate diversity (Rios \& Bailey, 2006). This method yields values that range from 0-1 (Wu, Zhang, Li-Fen, Jia-Kuan, \& Bo Li, 2008).

Invertebrates were separated into size classes. I determined the size classes by ranking invertebrates from largest to smallest and identifying natural breaks in the data. Four size classes were created large $\left(>0.93 \mathrm{~mm}^{2}\right)$, medium 
(0.27 mm $\left.\mathrm{m}^{2}-0.92 \mathrm{~mm}^{2}\right)$, small $\left(0.10 \mathrm{~mm}^{2}-0.91 \mathrm{~mm}^{2}\right)$, extra small $\left(0.001 \mathrm{~mm}^{2}-0.10\right.$ $\left.\mathrm{mm}^{2}\right)$.

\section{Ambient Condition Sampling}

In 2011 on July 27 and 28, August 25 and 26, and September 25 and 26, research assistants collected water chemistry (DO and water temperature) in the mid water column using a multimeter and I recorded optical assessments of algal growth at every sampling location. I used digital photography to document vegetative canopy and bank conditions within the reach. Photographs were taken looking downstream, bank left and right, and upstream. Canopy cover and habitat complexity (undercuts, submerged roots, and emergent vegetation) were recorded using a modified SWAMP protocol (Ode, 2007) on July 27 and 28,

2011. SWAMP protocol uses optical assessments based on percentages recorded on a 0-5 scale. The optical assessments are based on estimated percent cover of the different variables. Ambient conditions were recorded within the treatment reaches at invertebrate sampling points, and all data was collected within $5 \mathrm{~m}$ up and downstream (Ode, 2007). I conducted all optical assessments to reduce variability from potential bias.

Substrate sampling method followed SWAMP protocol. On June 27 and 28,2011 , I randomly selected a substrate particle from the streambed at each transect at five equidistant points along the transect. The length and width of 
each particle was recorded, and then categorized using a numerical scale (1-5) based upon average surface area (Ode, 2007).

\section{Data Analysis}

\section{Background Data}

Differences among stream geomorphology features in terms of invertebrate diversity and abundance, and water chemistry were assessed using a repeated-measure ANOVA.

I assessed static ambient conditions data including canopy cover, submerged tree roots, undercuts, emergent vegetation, and percent barren ground with a $t$-test between restored and control sites. Ambient conditions that fluctuated over time such as percent cover algae, DO, and temperature were analyzed using a repeated-measure ANOVA. All ambient conditions were compared by habitat type and by sampling reach to check for variations between habitat types and upstream and downstream effects.

\section{Effects of LWD Treatment Analysis}

To determine if abundance, diversity, species number, and size classes varied through time between the LWD treatments and control samples, I conducted repeated-measure ANOVAs comparing reaches with LWD installations with the nearest unaltered sampling reaches $(n=6)$ across the entire 2011 season (repeated June, July, August, September). In addition, to identify 
possible transient effects of LWD treatments during any given sampling period, (monthly) $t$-tests comparing LWD treatment sites and unaltered controls were run on all response variables (Watts \& Halliwell, 2006). All data that were not normally distributed were log transformed to meet the normalcy assumption, unless it contained zeros. Data that contained zeros were not transformed.

Substrate particle size and ambient conditions (canopy cover, submerged tree roots, undercuts, emergent vegetation, and percent barren ground) between LWD treatment and control sites was analyzed using a $t$-test. A repeatedmeasure ANOVA was used to assess percent cover algae, DO, and temperature between LWD treatments and controls throughout the study period.

\section{Results}

Over the course of the study, I collected 37 different morphospecies in 15 different orders. A total of 3,058 individual invertebrates were collected over the four month sampling period. The most abundant order collected was Ephemeroptera $(n=1,613)$ followed by Trichoptera $(n=465)$ and Diptera $(n=415)$. In the paired sample sites used in the LWD effects analysis, I collected 1,245 total invertebrates in 23 different orders. Ephemeroptera $(n=661)$ was most abundant order followed by Diptera $(n=124)$. Though Trichoptera had the second highest species number overall, only 80 individuals were collected in the sample sites used in the treatment and control analysis. 
Riffles were the least abundant $(n=3)$ habitat encountered during the randomized sampling in the reaches. Pool habitats dominated $(n=18)$ the sites sampled, followed by glides ( $n=6)$. Riffles had significantly higher monthly species abundance than did pools and glides (repeated-measure ANOVA; $F(2,18)=9.94, p=.001)$ (Figure 4). June, July, and August showed the greatest variation in abundance riffle compared to pools and glides, but this difference diminished in September. No significant difference in abundance or diversity was observed between glides and pools over the sampling period (repeated-measure ANOVA; $F(1,16)=0.02, p=.893)$.

No significant difference between habitat features including canopy cover, percent cover of algae, submerged tree roots, emergent vegetation, and percentage of barren ground treatment versus control or within each sampling reach was seen (t-test; $p>.05$ (for all analyses)).

\section{Characteristics of LWD Installation}

Significantly smaller substrate particles were found across sites where LWD structures were installed compared to control sites $(t(10)=5.33, p=.018)$ (Figure 5).

DO levels were also higher in control sites than in areas that received LWD treatment (repeated measure ANOVA; $F(1,10)=7.29, p=.022$ ) (Figure 6). No difference in DO was seen between pool and glide habitats (repeatedmeasure ANOVA; $F(1,10)=0.01, p=.97)$. Temperature was not significantly 
different between treatment and control (repeated-measure ANOVA;

$F(1,10)=0.82, p=.65)$ or pool and glide habitats (repeated-measure ANOVA;

$F(1,10)=0.62, p=.45)$.

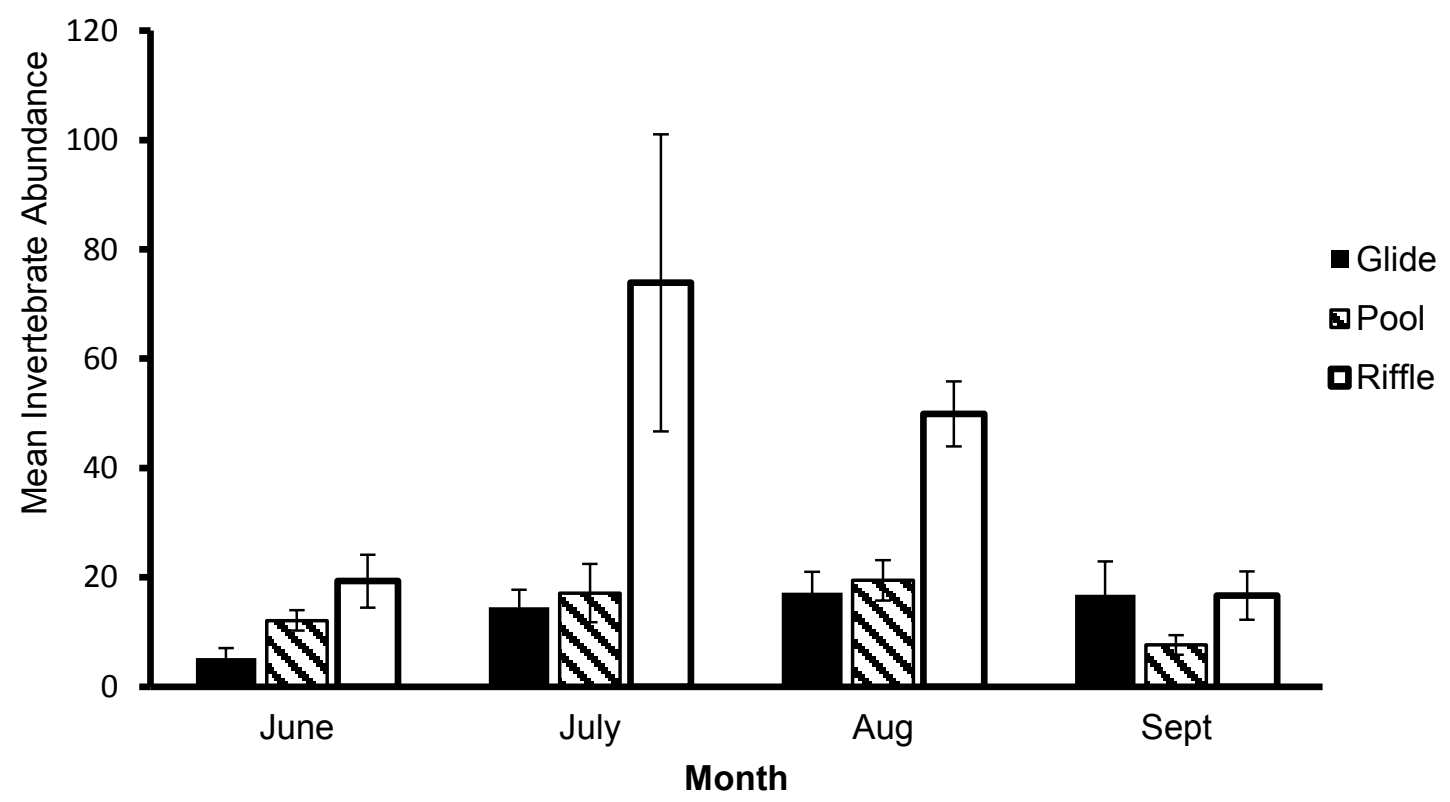

Figure 4. Mean invertebrate abundance per sample of glide, pool, and riffle habitats without LWD treatments (controls). Riffles contained the greatest abundances of invertebrates in June, July and August, with differences among habitat types diminishing by September. Overall invertebrate abundance was greatest in July and August, 2011. (Repeated measure ANOVA; $N=20$, $F(2,18)=9.94, p=.001$; error bars represent standard error around the mean.) 


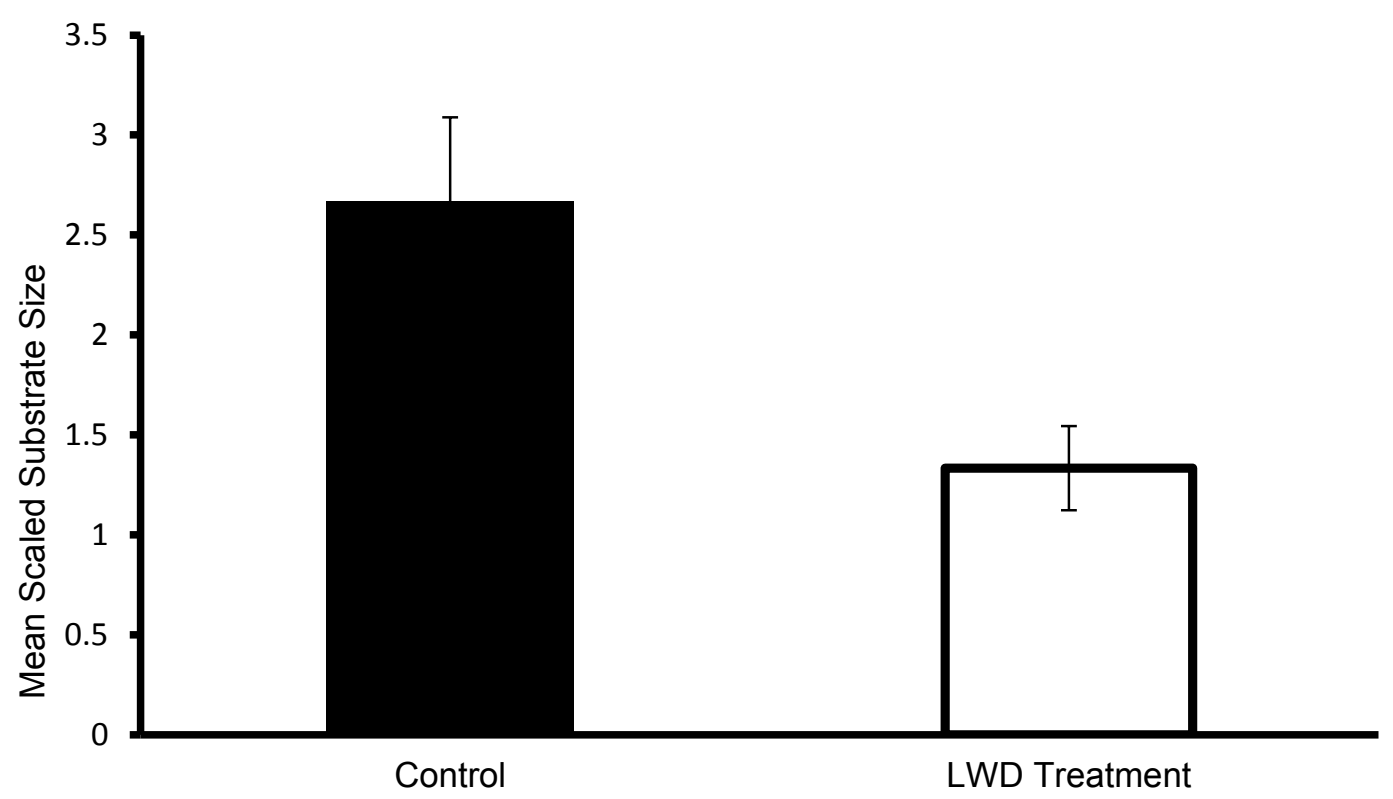

Figure 5. Mean substrate size (based on a 1-5 scale) was lower in large woody debris treatment versus control reaches. ( $t$-test; $n=6 ; t(10)=5.33, p=.018$; error bars represent standard error around the mean.)

Total species abundance did not differ significantly between LWD treatment and control sites across all the sample dates (repeated measures ANOVA, $F(1,10)=2.297 ; p=.161)$, but abundances did differ in some months. In August, a lower total invertebrate abundance was seen in areas that received treatment versus those that did not $(t$-test, $t(10)=5.28, p=.044)$ (Figure 7$)$. In June, July, and September, mean invertebrate abundances were not significantly different between treatment and control $(t$-test; June $t(10)=2.04, p=.184$; July $t(10)=0.06 ; p=.097$, September $t(10)=1.19, p=.30)$, but the numeric treatment abundance was consistently below that of the control. In no instances did the treatment create a higher invertebrate abundance. 


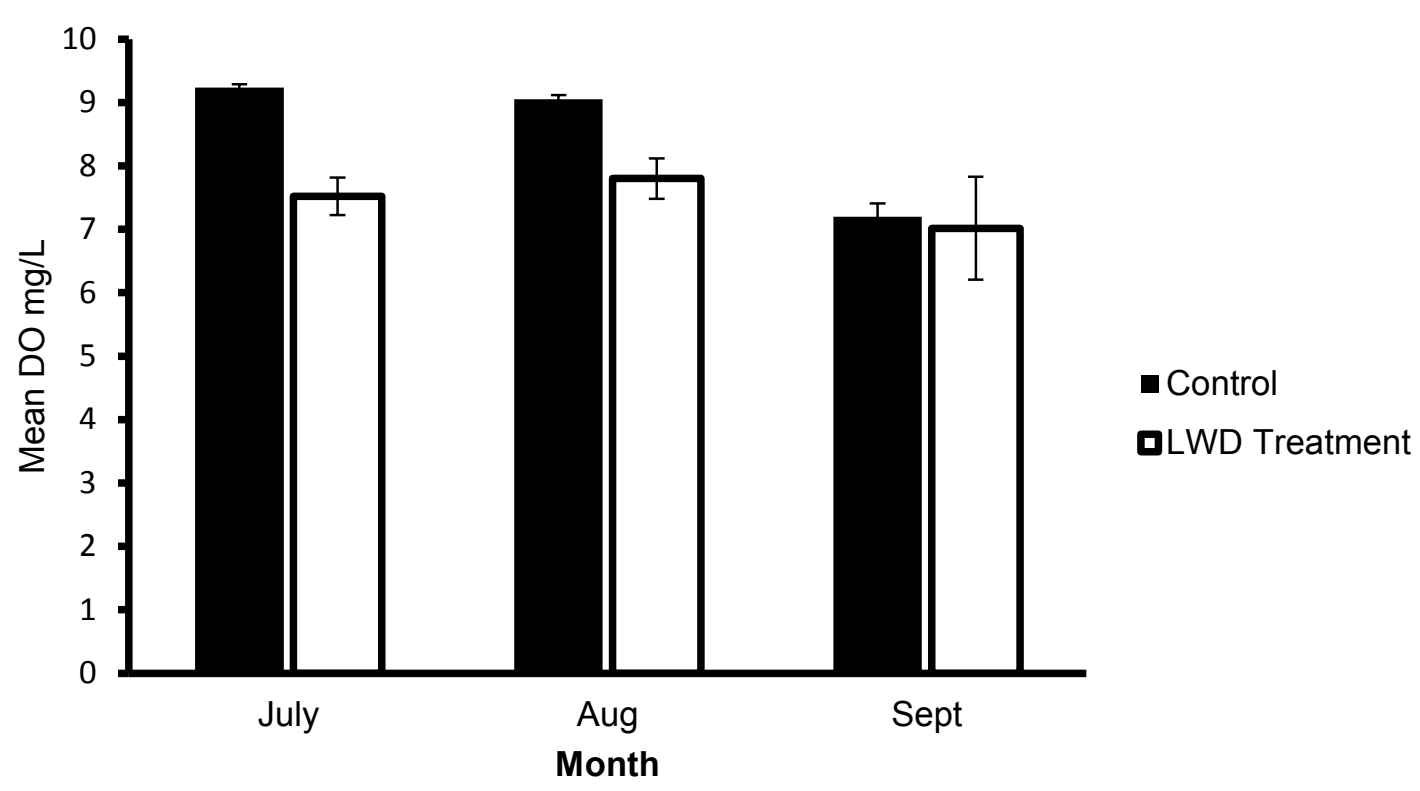

Figure 6. Mean DO reading in $\mathrm{mg} / \mathrm{L}$ over three month sampling period in large woody debris treatments versus control reaches. July and August provided similar results with September showing a cumulative drop throughout the study site. (Repeated measures ANOVA; $n=6 ; F(1,10)=7.29, p=.022$; error bars represent standard error around the mean.)

Simpson's diversity index and species richness were also not significantly different over the entire sampling period in the treatment versus control (repeated measures ANOVA; diversity $F(1,10)=0.04 p=.851$; richness $F(1,10)=2.71$, $p=.131)$, but species richness was lower in August $(t$-test; $t(10)=7.34, p=.022)$ (Figure 8). Simpson's diversity was not influenced by the treatments in any given month, and showed no significant change over the course of the study. 


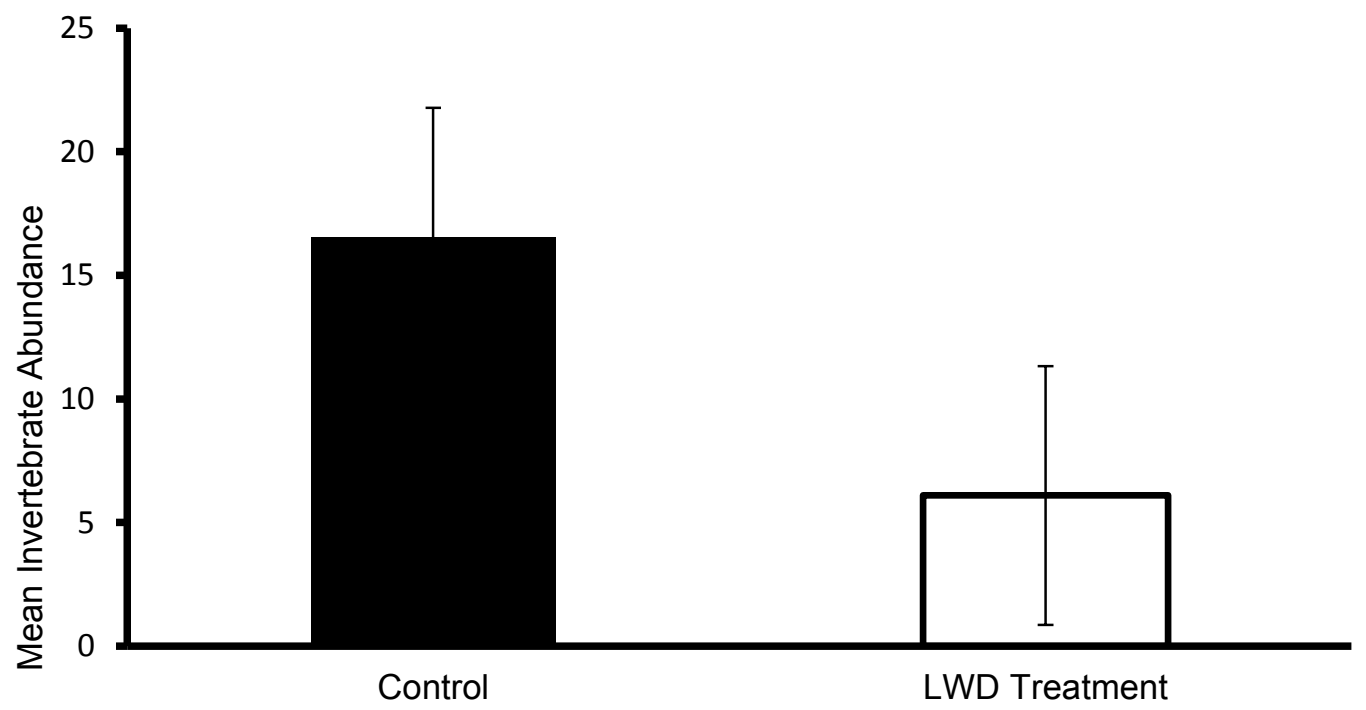

Figure 7. Mean invertebrate abundance was lower in large woody debris treatment versus control sites in August, 2011. ( $t$-test; $n=6 ; t(10)=5.28, p=.044$; error bars represent standard error around the mean.)

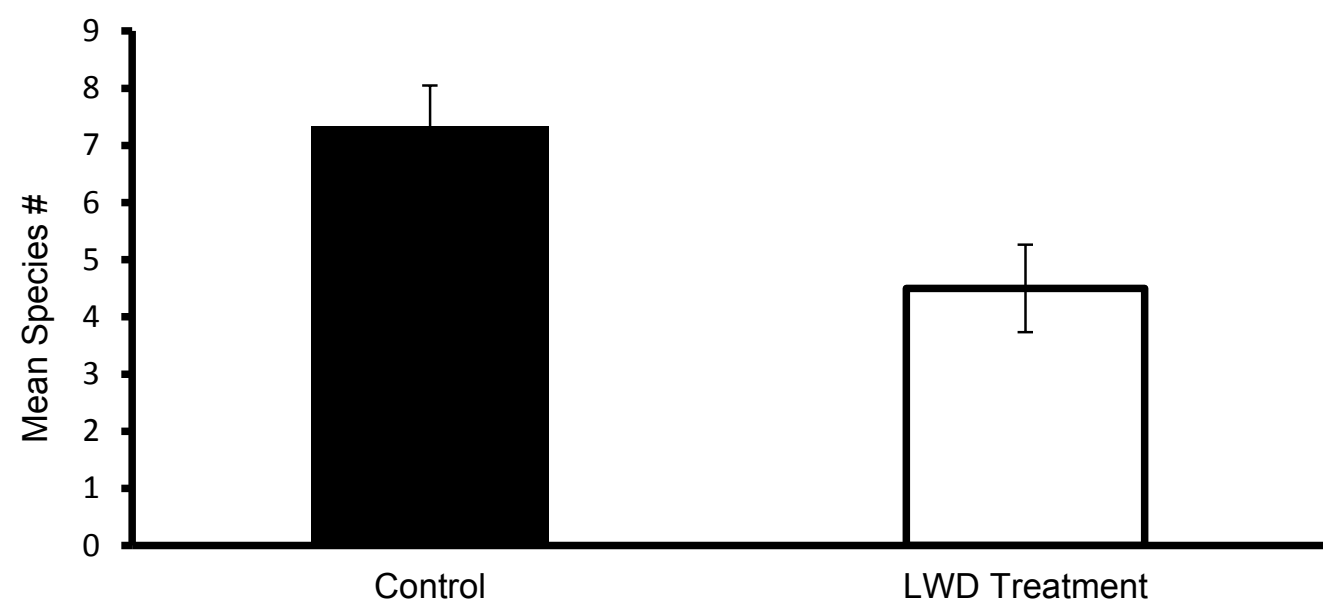

Figure 8. Mean species richness was lower where large woody debris treatments were installed versus control sites in August, 2011. ( $t$-test; $n=6 ; t(10)=7.34$, $p=.022$; error bars represent standard error around the mean.) 
Lower abundance was seen in August at the medium size class level ( $t$ test; $t(10)=7.79, p=.05)$ (Figure 9) in LWD treatment site when compared to unaltered control sites, but not at any other sampling date or size class.

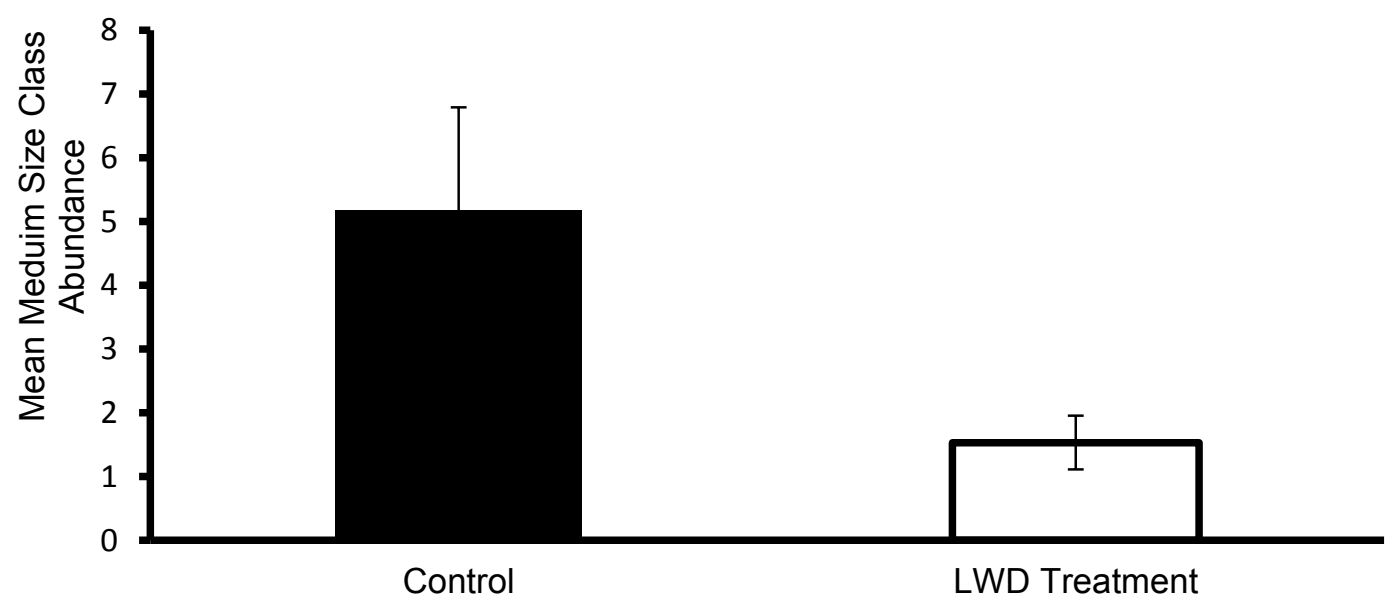

Figure 9. Mean medium size class abundance was lower where large woody debris treatments were installed versus control sites in August, 2011 ( $t$-test; $n=6$; $t(10)=7.79, p=.05$; error bars represent standard error around the mean.)

Ephemeroptera and Diptera were the only orders with great enough abundances to be analyzed individually. Ephemeroptera abundance was relatively similar between LWD treatment and control sites until the month of August, when abundances were lower in LWD treatments $(t$-test; $t(10)=7.59$, $p=.02)$ (Figure 10). The most abundant Ephemeroptera family, Leptohyphidae (little stout crawler), appeared to contribute substantially to the decline, with a declining tendency (repeated measure ANOVA; $F(1,10)=3.52, p=.09$ ) in treatment as contrasted with controls across all sampling days. The order 
Diptera was the second most abundant order collected. Both June and August showed a significantly smaller abundances ( $t$-test; June $t(10)=7.66, p=.02$, August $t(10)=4.62, p=.05)$ in Diptera larvae in LWD treatment versus control sites (Figure 11, and 12). In no instance were more invertebrates of any order in LWD treatments compared to control sites.

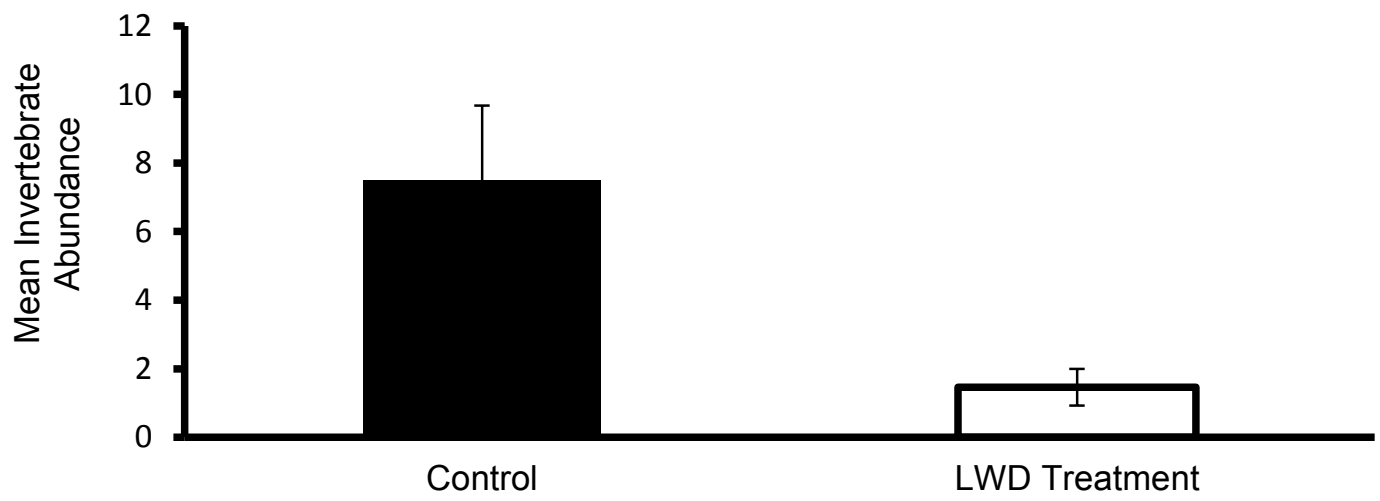

Figure 10. Mean Ephemeroptera abundance was lower in August, 2011 where large woody debris treatments were installed versus control reaches ( $t$-test; $n=6$; $t(10)=7.59, p=.02$; error bars represent standard error around the mean.)

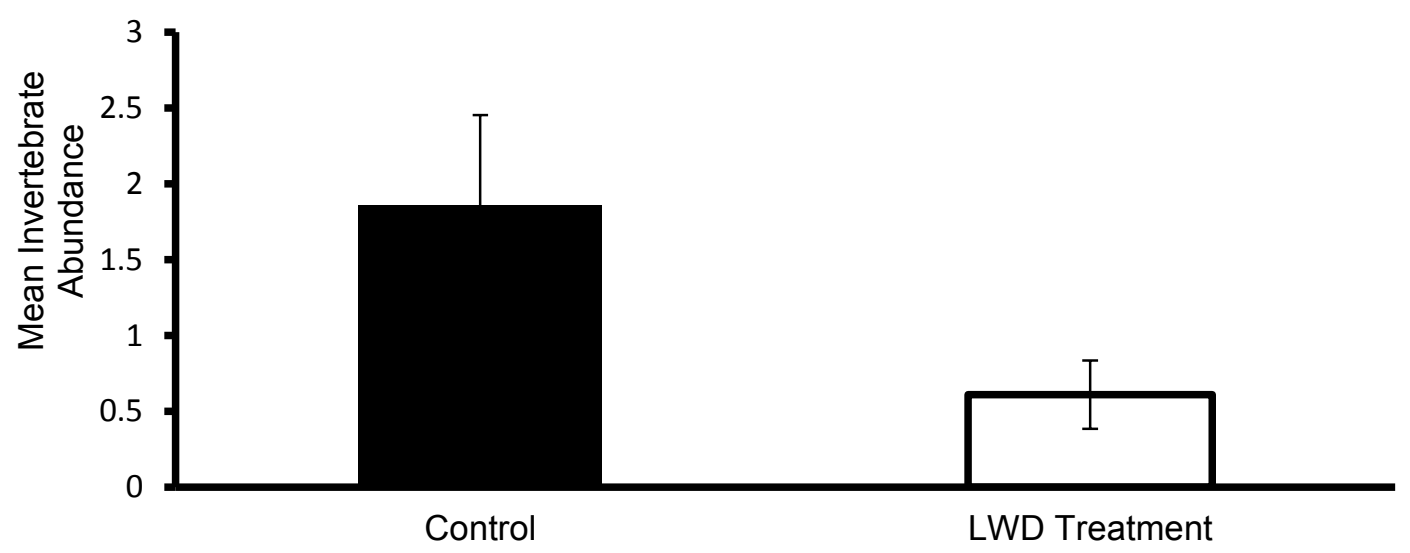

Figure 11. Diptera larvae were less abundant in large woody debris installations compared to control reaches in June, 2011. ( $t$-test; $n=6 ; t(10)=7.66, p=.02$; error bars represent standard error around the mean.) 


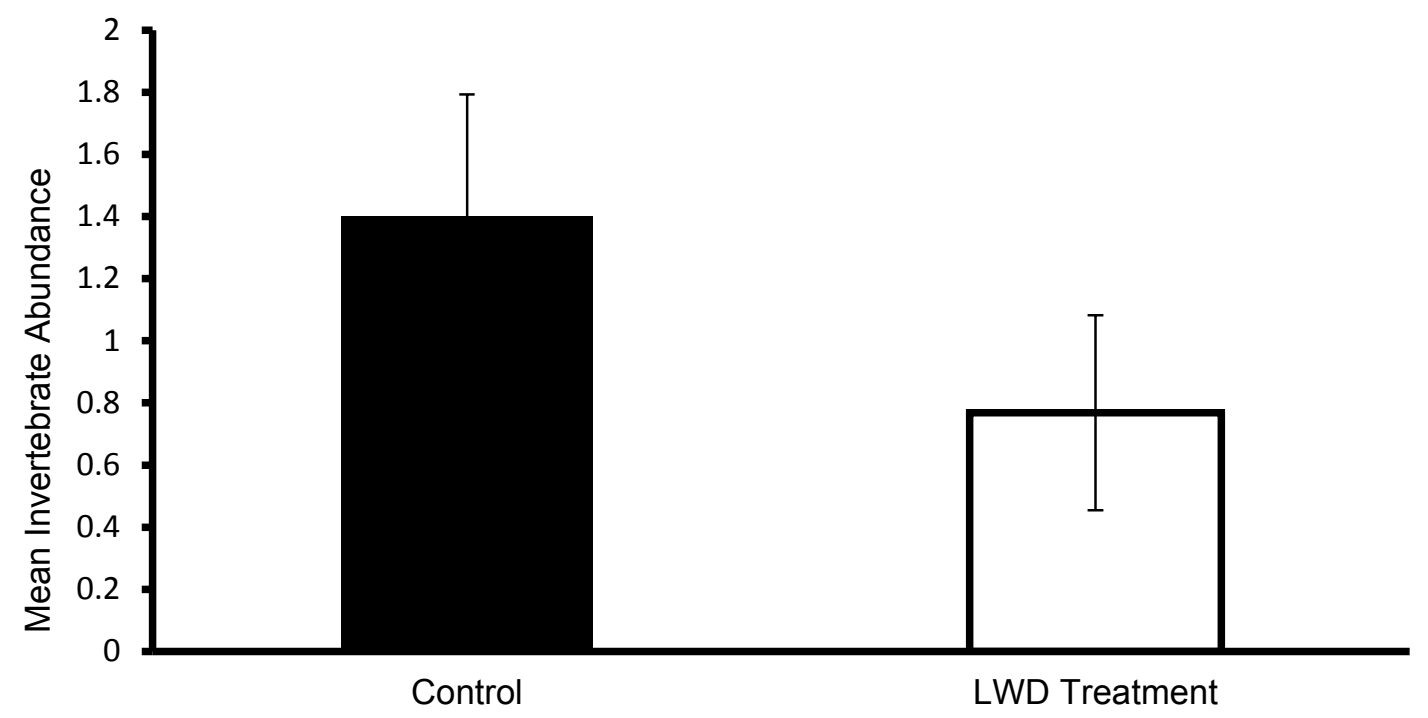

Figure 12. Diptera larvae were less abundant in large woody debris installations compared to control reaches in August, 2011. ( $t$-test; $n=6 ; t(10)=4.62, p=.05$; error bars represent standard error around the mean.)

\section{Discussion}

This study provides evidence that LWD restoration in the form of spider and bench logs did not increase invertebrate abundance or diversity in the first year after installation compared to unaltered control sites, and that, in fact, it led to transient difference in invertebrate abundance and species number during the first summer. Also, smaller substrate size and lower DO levels compared to control sites indicated that the structures were not functioning as intended during base flows.

There is significant evidence that habitat complexity through the installation of LWD, under some circumstances may be beneficial to benthic 
invertebrate diversity and abundance (e.g., Hrodey, Kalab, \& Sutton 2008), but the current study showed that in the first year of installation log structures did not achieve such benefits over unaltered control sites. Monthly invertebrate richness and diversity was similar for most months but depressed both severely in August and impacted individual taxa in June. This finding echoes that of Lepori et al. (2005) who determined that the installation of LWD does not benefit invertebrates if consideration is not given to the basic needs of the target organism. These structures were installed to benefit fish and reduce erosion. In theory, the structures would have benefited invertebrates if they performed as they had been designed, but it was determined that during base flow installed LWD in this project did not achieve basic geomorphological goals in the first year after installation and they may in fact have reduced the quality of the habitat for benthic invertebrates.

Reductions seen at a monthly level are significant as it indicates that these structures have the potential to limit invertebrate success under certain conditions. If the conditions that cause the decline in abundance in August were to occur for multiple months (in instances of low water years and warm summer temperature) the food available for fish could be drastically limited.

The overarching geomorphological goal of installing the LWD structures was to create beneficial habitat for salmonids by increasing channel complexity. According to Mossop and Bradford (2004), the installation of LWD structures 
should result in a more oxygenated system based on mechanical mixing. LWD structure in this system, however, did not appear to increase mechanical mixing and LWD reaches showed oxygen levels lower than nearby controls of the same habitat type. It seemed that LWD structures were installed in a fashion that did not allow for water to flow over during base flows in the first year. Limited base flows reduced the mechanical mixing rather than enhancing it, with LWD serving more as a barrier, slowing flows and decreasing oxygen availability. During kick sampling I experienced a smell of sulfides escaping from the sediments near structures that were not observed in control sites. This indicates the start of or hypoxic conditions. The DO levels that were observed at LWD treatment sites were not low enough to limit biological success of salmonids, but they were significantly lower than the control sites. Although levels of DO measured were not lethal to fish, DO levels are a limiting factor for invertebrate species and may have reduced invertebrate biological success (Connelly, Crossland, \& Pearson, 2004; Davison, Breese, Warren, \& Doudoroff, 1959). The DO levels in the substrate could be lower than what was tested mid water column, especially with the hypoxic conditions experienced. The base flow DO levels during the study period were not improved by the presence of LWD. However, if the structures were set lower in the channel, they might have increased base flow complexity and improved DO levels. The reductions that were seen were not drastic at the current flow levels, but the fact that the structures showed any decline is concerning. Knowing that the structures have the potential to lower DO is a 
factor that should be considered in future projects. The reduction in DO could be accentuated in low water years and could influence water quality downstream of the structures.

In restoration projects of this sort, LWD structures are intended to promote scour and deposition of bed material creating a heterogeneous streambed (Brooks, Gehrke, Jansen, \& Abbe 2004). In their first year the structures did not promote the deposition of larger material behind the structure, and they did not scour fine material in the first rainy season when compared to control sites. In areas near structures the substrate size was smaller than in the same habitat types in other parts of the system. Not only was the substrate small, it was more consistent with the texture of sand. Material transport and scour happens during high flow events. The increased velocity created by wood structures does not allow the deposition of fine material and removes fine material that settled during base flows (Brooks et al., 2004). The structures that were sampled had been through winter high flow events. However, the high winter flow events that occurred prior to the sampling period were relatively low due to a mild winter and staggered rain events, which may have resulted in low level of scour.

Fine sediment and lack of refugia between particles can contribute to the lack of abundance of invertebrates. Biggs and Holomuzki (2003) determined that large sediment particles that are not easily transferred by flow events harbor 
more organisms. Homogeneous bed material can limit the species that successfully inhabit an area (Lamouroux, Doledec, \& Gayraud, 2004). Suttle et al. (2004) determined that fine sediment can drastically alter the ecosystem function especially during seasonal low flow events. They found that the presence of fine sediments decrease steelhead growth and caused invertebrate assemblages to shift from taxa that are available to salmonids to unavailable burrowing taxa. The kick sampling method I used may have contributed to not finding the burrowing taxa, indicating why a shift in diversity was not seen. If a shift in abundance and diversity of burrowing taxa did occur, it is not beneficial to salmonids as they are not readily available prey items (Suttle et al., 2004)

If fine substrates remain even after normal winter flow events, species composition could potentially change. Suttle et al. (2004) determined that invertebrate taxa shifted due to altered substrate size. It is unlikely that this change will occur in the Rutherford Reach Restoration Project as Matthaei, Uehlinger, Meyer, and Frutiger (1996) determined that when re-colonization occurs it happens rapidly especially in summer months. Matthaei et al. (1996) showed levels equivalent to undisturbed condition in less than 30 days.

When looking at the specific changes in invertebrates, the little stout crawler mayfly (Ephemeroptera; Leptohyphidae) stands out as the most sensitive to the restoration efforts. The little stout crawler was the most abundant family collected. This family dominated the medium size class, the size that showed the 
most change in effects of LWD installation. The lower abundances in this taxon were responsible for the reduction in both Ephemeroptera and the medium size class data in LWD treatments. Tippet and Moyle (1978), among others (White \& Harvey, 2007; Mcintosh, Peckarsky, \& Taylor, 2002), have demonstrated that Ephemeroptera is a primary food source for salmonids. Little stout crawler is beneficial to salmonids due to its size and availability. This particular taxon falls into the feeding guild of collector. It moves through the substrate in search of food (Stehr, 2007). This feeding behavior makes little stout crawler more readily available to salmonids. Though salmonids are opportunistic feeders, and can shift their diet to available forage, the decline in a primary food source could limit the success of the species (Tippet \& Moyle, 1978).

This study was a short-term look into the initial results of LWD structures in the Napa River during the first summer after installation. Having abnormal rainfall amounts and patterns could have influenced the study and lead to the results that were seen. The fact that these structures were placed in degraded areas that were lacking beneficial habitat could be a contributing factor to the limited success that was seen during the first year of installation. As the restoration matures over multiple seasons short-term effects such as the reduction in invertebrate abundance and diversity and the decline in DO and substrate size may improve. A riparian system with threatened species should not experience any lapse in biological integrity. Species such as steelhead and Chinook salmon are likely too sensitive to tolerate habitat that is not functioning. 
All aspects of the restoration should be considered to allow for continuous function from start to finish.

\section{Recommendations}

Findings from this study provide a reminder that restoration projects must be carefully monitored for success, especially in the first few years after implementation. Restoration is an intrinsically dynamic and experimental field, with both failures and successes. Frequently, restoration is proposed as mitigation for habitat destruction or increased human impact. If policy makers are to accept such propositions, they should carefully assess the short and longterm risks inherent in the practice of ecological restoration, even in systems as well-documented as riparian corridors.

Specifically, precautions should be taken to avoid unexpected and catastrophic effects of restoration construction in the first few years:

- Multiple LWD structures should be installed in phases, not within the same season. This would limit potential areas of reduced food availability. If LWD structures were installed in a large portion of the streambed simultaneously, a decrease in available food could be seen, limiting the production of salmonids.

- Future structures should be installed to influence base flow regimes. Having the structures lower in the channel would increase base flow velocity, in turn reducing the deposition of fine material and increasing 
available DO. These changes would not drastically change the function of winter refugia and would still serve as bank protection.

- If this is not possible, consideration should be given to installing structures with salmonid habitat as its only function. No emphasis should be placed on bank protection, and structures should be modeled after natural occurring LWD in the system.

- Combining other restoration strategies, such as gravel augmentation with LWD structures to limit the impacts associated with substrate size that was observed in this study could be valuable. The lack of invertebrate abundance might in fact be mitigated by providing substrate of adequate size to promote beneficial invertebrates. The structures should function in a way as to retain the augmented gravel, and also reduce embeddedness of the particles.

- Future monitoring and research of the effects of the LWD structures should continue so further conclusions can be drawn. The data collected in this study would serve as a valuable baseline to determine changes over time. 


\section{References}

Anderson, W. B. \& Waits, A. (2001). Subsidized island biography hypothesis: another new twist on an old theory. Ecology Letter, 4, 289-291.

Berggren, A., Birath, B., \& Kindvall, O. (2002). Effect of corridors and habitat edges on dispersal behavior, movement rates, and movement angles in Roesel's bush-cricket (Metrioptera roeseli). Conservation Biology, 16, 1562-1569.

Blocksom, K. A., Autrey, B. C., Passmore, M., \& Reynolds, L. (2008). A comparison of single and multiple habitat protocols for collecting macroinvertebrates in wadeable streams. Journal of the American Water Resources Association, 44, 577-593.

Borin, M., Passoni, M., Thiene, M., \& Tempesta, T. (2010). Multiple functions of buffer strips in farming areas. European Journal of Agronomy, 23, 103111.

Brooks, A. P., Gehrke, P. C., Jansen, J. D., \& Abbe, T. B. (2004). Experimental reintroduction of woody debris on the Williams River, NSW: geomorphic and ecological responses. River Research and Applications, 20, 513-536.

Correll, D. L. (2005). Principles of planning and establishment of buffer zones. Ecological Engineering, 24, 433-439.

Connolly, N. M., Crossland, M. R., \& Pearon, R. G. (2004). Effect of low dissolved oxygen on survival, emergence, and drift of tropical stream macroinvertebrates. Journal of North American Benthological Society, 23, 251-270.

Cummins, K.W., Wilzbach, M.W., Gates, D.M., Perry, J.B. \& Taliaferro, W.B. (1989). Shredders and riparian vegetation. Bioscience, 39, 24-30. 
Davison, R. C., Breese, W. P., Warren, C. E. \& Doudoroff, P. (1959). Experiments on dissolved oxygen requirements of cold-water fishes. Sewage and Industrial Wastes, 31, 950-966.

Duehr J. P., Seipker M. J., Pierce C. L., \& Isenhart, T. M. (2008). Relation of riparian buffer strips to in-stream habitat, macroinvertebrates and fish in a small lowa Stream. Journal of lowa Academic Sciences, 113, 101-107.

England, L. E. \& Rosemond, A. D. (2004). Small reductions in forest cover weaken terrestrial aquatic linkages in headwater streams. Freshwater Biology, 49, 721-734.

Froman, R. T. T. (1995). Land Mosaics: The ecology of landscapes and regions. Cambridge University Press, New York, New York.

Gamito, S. \& Furtado, R. (2009). Feeding diversity in macroinvertebrate communities: A contribution to estimate the ecological status in shallow waters. Ecological Indicators, 9, 1009-1019.

Gortz, P. (1998). Effects of Stream restoration on macroinvertebrate communities in River Esrom, Denmark. Aquatic Conservation: Marine and Freshwater Ecosystems, 8, 115-130.

Gowan, C. \& Faush, K. D. (1996). Long-term demographic responses of trout populations to habitat manipulation in six Colorado streams. Ecological Applications, 6, 931-946.

Gregory, S. V., Swanson, F. J., Mckee, W. A., \& Cummins, K. W. (1991). An Ecosystem Perspective of Riparian. BioScience, 41, 540-551.

Growns, I., Schiller, C., O'Connor, N., Cameron, A., \& Gray, B. (2006). Evaluation of four live-sorting methods for use in rapid biological assessments using macroinvertebrates. Environmental Monitoring and Assessment, 117, 173-192. 
Harding, J. S., Claassen, K. \& Evers, N. (2006). Can forest fragments reset physical and water quality conditions in agricultural catchments and act as refugia for forest stream invertebrates? Hydrobiologia, 568, 391-402.

Hawkins, C. P., Hogue, J. N., Decker, L. M., \& Feminella, J. W. (1997). Channel morphology, water temperature, and assemblage structure of stream insects. Journal of the North American Benthological Society, 16, 728749 .

Hayes, G. E., Micheli, L., \& MacKay, K. (2010). Monitoring plan for the Rutherford Reach Restoration of the Napa River with site-specific detail for phase I (reaches 1 and 2) and phase II (reach 3). 07-542-550-0 State Water Resources Control Board.

Sarrow, J., \& Sharp, L. (2011). Napa River Ruterford Reach Restoration Project 2011 Monitoring Report. Tessera Consulting, Livermore, CA.

Heino, J., Paavola, R., Virtanen, R., \& Muitka, T. (2005). Searching for biodiversity indicators in running waters: do bryophytes, macroinvertebrates, and fish show congruent diversity patterns? Biodiversity and Conservation, 14, 415-428.

Holl, K. D. \& Crone, E. E., (2004). Applicability of landscape and island biogeography theory to restoration of riparian understorey plants. Journal of Applied Ecology, 41, 922-933.

Hrodey, P. J., Kalab, B. J., \& Sutton, T. E. (2008). Macroinvertebrate community response to large-woody additions in small warmwater streams. Hydrobiologia, 605, 193-207.

Jergentz, S., Mugni, H., Bonetto, C., \& Schultz, R. (2005). Assessment of insecticide contamination in runoff and stream water of small agricultural streams in the main soybean area of Argentina. Chemosphere, 61, 817826. 
Johnson, L. B., Breneman, D. H., \& Richards, C. (2003). Macroinvertebrate community structure and function associated with large wood in low gradient streams. River Research Applications, 19, 199-218.

Johnson, S. L., Rodgers, J. D., Solazzi M. F., \& Nickelson, T. E. (2005). Effects of an increase in large wood on abundance and survival of juvenile salmonids (Oncorhynchus spp.) in an Oregon coastal stream, Canadian Journal of Fish and Aquatic Science, 62, 412-424.

Jones, K. L., Poole, G. C., Meyer, J. L., Bumback, W., \& Kramer, E. A. ( 2006). Quantifying expected ecological response to natural resource legislation: a case study of riparian buffers, aquatic habitat, and trout populations. Ecology and Society, 11, 15-29.

Kondolf, G. M. (2000). Some suggested guidelines for geomorphic Aspects for anadromus Salmonid Restoration proposals. Restoration Ecology, 8, 4856.

Kreutzweiser, D. P., Capell, S. S. \& Holmes, S. B. (2009). Stream temperature responses to partial-harvest logging in riparian buffers of boreal mixedwood forest watersheds. Canadian Journal of Forest Research, 39, 497-506.

Kupfer, J. A. (1995). Landscape ecology and biogeography. Progress in Physical Geography, 19, 18-34.

Lamouroux, N., Doledec, S., \& Gayraud, S. (2004). Biological traits of stream macroinvertebrates communities: effects of microhabitat, reach, and basin filters. Journal of the North American Benthological Society, 23, 449-466.

Lepori, F., Palm, D., Brannas, E., \& Malmqvist. (2005). Does restoration of structural heterogeneity in streams enhance fish and macroinvertebrate diversity? Ecological Applications, 15, 2060-2071. 
Lorion, C. M. \& Kennedy, B. P. (2009). Riparian forest buffers mitigate the effects of deforestation on fish assemblage in tropical headwater stream.

Ecological Application, 19, 468-479.

(2008). Relationship between deforestation, riparian forest buffers and benthic macroinvertbrates in neotropical freshwater stream. Freshwater Biology, 54, 165-180.

Luke, S. H., Luckai, N. J., Burke, J. M., \& Prepas, E. E. (2007). Riparian areas in the Canadian boreal forest and linkages with water quality in streams, Environmental Review, 15, 79-97.

Ma, M., Tarmi, S., \& Helenius, J. (2002). Revisiting the species-area relationship in a semi-natural habitat: floral richness in agricultural buffer zones in Finland. Agriculture, Ecosystem, and Environment, 89, 137-148.

Magilligan, F. J., Nislow, K. H., Fisher, G. B., Wright, J., Mackey, G., \& Laser, M. (2008). The geomorphic function and characteristics of large woody debris in low gradient rivers, coastal Maine, USA. Geomorphology, 9, 467-482.

Martin, D. J. \& Grotefendt, R. A. (2007). Stand mortality in buffer strips and the supply of woody debris to streams in Southeast Alaska. Canadian Journal of Forest Research, 37, 37-49.

Matthaei, C. D., Uehlinger, U., Meyers, E. I., \& Frutiger, A. (1996). Recolonization by benthic invertebrates after experimental disturbance in a Swiss prealpine river. Freshwater Biology, 35, 233-248.

Macarthur, R. H. \& Wilson, E. O. (1967). The Theory of Island Biogeography. Princeton University Press. Princeton, New Jersey.

Mcevoy, A. F. (1986). The Fisherman's Problem. Cambridge University Press. Cambridge, London, New York, New Rochelle Melbourne, and Sydney. 
Mcintosh, A. R., Peckarsky, B. L., \& Taylor, B. W. (2002). The influence of predatory fish on mayfly drift: extrapolating from experiments to nature. Freshwater Biology, 47, 1497-1513.

Meissner, K., \& Muotka, T. (2006). The role of trout in stream food webs: integrating evidence from field surveys and experiments. Journal of Animal Ecology, 75, 421-433.

Miller, S. W., Budy, P., \& Schmidt, J. C. (2010). Quantifying macroinvertebrate response to in-stream habitat restoration: Applications of meta-analysis to river restoration. Restoration Ecology, 18, 8-19.

Mossop, B. \& Bradford M. J. (2004). The importance of large woody debris for juvenile Chinook salmon habitat in small boreal forest streams in the upper Yukon River basin, Canada. Canadian Journal of Fish and Aquatic Science, 34, 1955-1966.

Muotka, T. \& Laasonen, P. (2002). Ecosystem recovery in restored headwater streams: the role of enhanced leaf retention. Journal of Applied Ecology, 39, 145-156.

Muotka, T. Paavola, R., Haapala, A., Novikmec, M., \& Laasonen, P. (2002). Long term recovery of stream habitat structure and benthic invertebrate communities from in-stream restoration. Biological Conservation, 105, 243-253.

Nagayama, A., Kawaguchi, Y., Nakano, D., \& Nakamura, F. (2009). Summer microhabitat partitioning by different size class of masu salmon (Oncorhynchus masou) in habitats formed by installed large wood in a large lowland river. Canadian Journal of Fish and Aquatic Science, 66, 4251.

Naiman, R. J., Decamps, H., \& Pollock, M. (1993). The Role of Riparian Corridors in Maintaining Regional Biodiversity. Ecological Applications, 3, 209-212. 
Netboy, A. (1958). Salmon of the Pacific Northwest. Binfords and Mort Publishers. Portland Oregon.

Nicholls, C. I., Parrella, A., \& Altieri, M. A. (2001). The effects of a vegetational corridor on the abundance and dispersal of insect biodiversity within a northern California organic vineyards. Landscape Ecology, 16, 133-146.

Ode, P. (2007). Standard operation procedure for collecting benthic macroinvertebrate samples as associated physical and chemical data for ambient bioassessment in California. California State Water Board.

Osborne, L. L. \& Kovacic, D. A. (1993). Riparian vegetated buffer strips in waterquality restoration and stream management, Freshwater Biology, 29, 243258.

Palmer, M.A., Ambrose, R.F. \& Poff, N.L. (1997). Ecological theory and community restoration ecology. Restoration Ecology, 5, 291-300.

Poole, G. C. (2010). Stream hydrogeomorphology as a physical science basis for advances in stream ecology. Journal of North American Benthological Society, 29, 12-25.

Poole, G. C., \& Berman, C. H. (2001). An ecological perspective on in-stream temperature: natural heat dynamics and mechanisms of human-caused thermal degradation, Environmental Management, 27, 787-802.

Richards, C., Host, G. E., \& Arthur, J. W. (1993). Identification of predominant environmental factors structuring stream macroinvertebrate communities within a large agricultural catchment. Freshwater Biology, 29, 285-294.

Rios, S. L. \& Bailey, S. L. (2006). Relationship between riparian vegetation and stream benthic communities at three spatial scales. Hydrobiologia, 553, 153-160. 
Romaniszyn, E. D., Hutchens, J. J., \& Wallace, J. B. (2007). Aquatic and terrestrial invertebrate drift in southern Appalachian Mountain streams: implications for trout food resources. Freshwater Biology, 52, 1-11.

Rosenfeld, J. S. \& Taylor, J. (2009). Prey abundance, channel structure and the allometry of growth rate potential for juvenile trout. Fisheries Management and Ecology, 16, 202-218.

Sarrow, J. (2011). Napa River Rutherford Reach Restoration Project Annual Maintenance and Monitoring Survey. Napa County Flood Control and Water Conservation District, Napa, CA.

Schneider, K. N., \& Winemiller, K. O. (2008). Structural complexity of woody debris patches influences fish and macroinvertebrate species richness in a temperate floodplain-river system. Hydrobiologia, 610, 235-244.

Shields, F. D., Knight, S. S., Morin, N., \& Blank, J. (2003). Response of fishes and aquatic habitats to sand-bed stream restoration using large woody debris. Hydrobiologia, 494, 251-257.

Simberloff, D., Farr, J. A., Cox, J., \& Mehlman, D. W. (1992). Conservation Bargains or Poor Investments? Conservation Biology, 6, 493-504.

Soluk, D. A. \& Richardson, J. S. (1997). The Role of Stoneflies in Enhancing Growth of Trout: A Test of the Importance of Predator- Predator Facilitation within a Stream Community. Oikos, 80, 214-219.

Spackman, S. C., \& Hughes, J. W. (1995). Assessment of minimum stream corridor width for biological conservation: species richness and distribution along mid-order streams in Vermont, USA. Biological Conservation, 71, 325-332.

Speaker, R.W., Luchessa, K.J., Franklin, J.F. \& Gregory, S.V. (1988). The use of plastic strips to measure leaf retention by riparian vegetation in a coastal Oregon stream. American Midland Naturalist, 120, 22-31. 
Stehr, F. W. (2007). Immature Insects. Dubuque, IA: Kendall/Hunt Publishing.

Suttle, K. B., Power, M. E., Levine, J. M., \& McNeely, C. (2004). How fine sediment in riverbeds impairs growth and survival of juvenile salmonids. Ecological Applications, 14, 969-974.

Sweka, J. A. \& Hartman, K. J. (2006). Effects of large woody debris addition on stream habitat and brook trout populations in Appalachian streams. Hydrobiologia, 559, 363-378.

Taylor, C. M. \& Warren, M. L. (2001). Dynamics in species composition of stream fish assemblages: environmental variability and nested subsets. Ecology, 82, 2320-2330.

Tippets, W. E. \& Moyle, P. B. (1978). Epibenthic feeding by rainbow trout (Salmo gairdneri) in the McCloud River, California. Journal of Animal Ecology, 47, 549-559.

Viers, J. H. (2008). Objective classification of Navarro River salmon habitat: a based critical habitat case study. Aquatic Conservation: Marine and Freshwater Ecosystems, 18, 147-162.

Watts, S. \& Halliwell, L. (1996). Essential Environmental Science: Methods and Techniques. Routledge: London and New York, New York.

Wauchope R. D. (1978). The pesticide content of surface water draining from agricultural fields-a review. Journal of Environmental Quality, 7, 459472.

White, J. L. \& Harvey, B. C. (2007). Winter feeding success of stream trout under different streamflow and turbidity conditions. Transactions of the American Fisheries Society, 136, 1187-1192. 
Wing, G. M. \& Skaugset, A. (2002). Relationships of channel characteristics, landownership, and land use patterns to large woody debris in western Oregon streams. Canadian Journal of Fish and Aquatic Science, 51, 796807.

Wu, Y., Zhang, W., Li-Fen, B., Jia-Kuan, J., \& Bo Li, C. (2009). Effects of saltmarsh invasion by Spartina alterniflora on arthropod community structure and diets. Biological Invasions, 11, 635-649. 